\title{
Avrupa Komşuluk Politikası'nda Demokrasi Teşviki: Ermenistan Örneği ve İç Dinamiklerin Değerlendirilmesi
}

\author{
Fulya AKGÜL DURAKÇAY*, Özge BOZKAYA**
}

Öz

Soğuk Savaş'ın sona ermesi ile birlikte uluslararası ilișkilerin güvenlik gündeminin değișmesi ile Avrupa Birliği (AB) 1990’ların sonundan itibaren demokrasiyi teşvik eden uluslararası bir aktör olarak evrilmiștir. AB, Avrupa Komşuluk Politikası'nda demokrasi teşvikini; Birlik normlarının, değerlerinin ve standartlarının komşu ülkelere aktarılması yoluyla güvenlik stratejisi temelinde ele almaktadır. AB'nin demokratikleşme süreçlerinin ülke içi dinamikler ile iç içe olduğunu kabul ettiği demokrasi teşviki politikalarının başarısı, üçüncü ülkelerin istek, irade ve yetkinliklerine bağımlı kalmaktadır. Bu çalışmada, AB’nin demokrasi anlayışı ve demokrasi teşviki politikası Komşuluk Politikası ve Ermenistan örneği üzerinden incelenmektedir. AB'nin Ermenistan ile kurumsal ilişkileri demokrasi teşviki bağlamında tarihsel olarak incelenmekte ve AB'nin koşulluluk ve sosyalleşme mekânizmalarına ne ölçüde başvurduğu analiz edilmektedir. Ermenistan'ın kurumsal yapısı, geleneksel yönetim anlayıșı, sivil toplumun gelișmesinin önündeki engeller ve ülkedeki siyasi, iktisadi, sosyal ve askeri Rusya nüfuzu Ermenistan'da demokrasi teşviki sürecindeki $\mathrm{AB}$ etkisini belirleyici unsurlar olarak ele alınmaktadır.

Anahtar Kelimeler: Avrupa Birliği, Avrupa Komşuluk Politikası, Demokrasi Teşviki, Ermenistan, İç Dinamikler

\section{Democracy Promotion in the European Neighbourhood Policy: The Case of Armenia and an Assessment of Internal Dynamics}

\section{Abstract}

The European Union (EU) has evolved as an international democracy promoter actor since the 1990s as the security agenda of the international relations have changed with the end of the Cold War. The EU approaches its democracy promotion within the basis of its security strategy through the transfer of the EU norms, values and standards to neighbouring states in the European Neighbourhood Policy. The EU by admitting that the process of democratisation is intertwined with domestic contexts is dependent on

\section{Özgün Araştırma Makalesi (Original Research Article) \\ Geliş/Received: 26.11 .2018 \\ Kabul/Accepted: 11.04 .2019 \\ DOI: http://dx.doi.org/10.17336/igusbd.486612}

* Arș. Gör., Dokuz Eylül Üniversitesi, İşletme Fakültesi, Uluslararası İlişkiler Bölümü, İzmir, Türkiye, E-posta: fulya.akgul@deu.edu.tr, fulya.akgul@hotmail.com ORCID ID https://orcid.org/0000-00030200-7911

${ }^{* *}$ Doktora Öğrencisi, YÖK 100/2000 Göç Çalışmaları Bursiyeri, Dokuz Eylül Üniversitesi, Sosyal

Bilimler Enstitüsü, Avrupa Çalışmaları Anabilim Dalı, İzmir, Türkiye,

E-posta: ozgebozkaya5@gmail.com ORCID ID https://orcid.org/0000-0003-3389-3370 
third countries' desires, wills and competences for the success of its democracy promotion policies. This study analyses the EU's comprehension of democracy and democracy promotion policies within the context of the Neighbourhood Policy and the case of Armenia. The EU's institutional relations with Armenia are analyzed historically on the basis of its democracy promotion and the extent that the EU adheres to the mechanisms of conditionality and socialization is evaluated. Armenia's institutional structure, its traditional administration approach, impediments for the development of civil society and Russian political, economic, social and military dominance in Armenia are discussed as determining factors for the EU's impact on Armenia's democracy promotion process.

Keywords: The European Union, The European Neighbourhood Policy, Democracy Promotion, Armenia, Internal Dynamics

\section{Giriş}

Soğuk Savaş'ın sona ermesi ile demokrasiye geçen ülkelerin sayısı artmış ve Avrupa Birliği $(\mathrm{AB})$ değişen güvenlik gündemi ile birlikte demokrasiyi teşvik eden uluslararası bir aktör rolünü üstlenmiştir. 2004 genişlemesi ile AB'nin sınırları Doğu Avrupa'ya doğru kaymış ve komşuları değişmiştir. En geniş katılımlı bu genişleme neticesinde, $A B^{\prime}$ nin karşı karşıya olduğu güvenlik tehditleri değişmiş ve genişlemenin sınırlılığı dile getirilmeye başlanmıștır. Bu durum, Birliğin komşularına üyelikten az, işbirliğinden fazla bir vaat sunacağı bir politika oluşturmasında etkili olmuştur. $\mathrm{Bu}$ doğrultuda, $A B$ 'nin bir dostlar halkasına ihtiyacı olduğu savından hareketle oluşturulan Avrupa Komşuluk Politikası, üyelik vaadinin yer almadı̆̆ fakat komşulardan demokratikleşme yönünde birtakım reformların beklendiği yapısal bir dış politika anlayışı ile birleștirilmiștir. 2004 yılında yayımlanan Komşuluk Strateji Belgesi uyarınca Ermenistan dâhil olmak üzere 16 komşu ülkenin yer aldığı bu politikada, hukukun üstünlüğü ve demokrasinin yayıldığı güvenli, istikrarlı ve dinamik demokrasilerin varlığı en önemli unsurlardan biri olarak belirlenmiştir.

$\mathrm{AB}$, Komşuluk Politikası çerçevesinde demokrasi teşvikini dış ve güvenlik politikasının amacı ve aracı olarak sunmaktadır. Demokrasi teşvikinde demokratik koşulluluk ve sosyalleşme mekânizmasını kullanan $A B$, demokratikleşme sürecinin komşu ülkelerin istek, irade ve reformları gerçekleştirme çabalarına bağlı olan iki taraflı bir süreç olduğuna işaret etmektedir. Böylelikle, Ermenistan örneği üzerinden incelenen bu çalışmada görüleceği üzere demokratikleşmede $A B$ etkisinin koşulluluk ve sosyalleşme aracılığı ile özellikle eski Sovyet ülkelerine nüfuz etmesinin önünde, ülkelerin kendi iç dinamiklerinin etki alanı önemli bir gündem maddesidir. Demokrasi teşviki doğrultusunda AB'nin Ermenistan'dan beklediği siyasi reformlar demokratik kurumların kapasitenin geliștirilmesi, adil, özgür ve şeffaf seçimlerin gerçekleștirilmesi ve sivil toplumun güçlendirilmesi ile sıkı sıkıya ilişkilidir. Eski Sovyet ülkelerinde devam etmekte olan ulus-devlet inşa etme süreçleri göz önünde bulundurulduğunda, $\mathrm{AB}$ demokrasi teşviki çerçevesinde üçüncü ülkelere yayılması hedeflenen normatif değerlerin ve kuralların üyelik vaadinin yer almadığı Komşuluk Politikası altında sınırlı bir etkinlik alanı bulunmaktadır.

Çalışmada, ilk olarak AB'nin demokrasi teşviki anlayışı incelenmektedir. $\mathrm{Bu}$ amaçla, AB'nin demokrasi teşviki politikalarını geliştirmesinde ve demokrasi anlayışını sunmasında kaynaklık eden temel belgeler incelenmektedir. Daha sonra, Ermenistan'ın içinde yer aldığı Avrupa Komşuluk Politikası'nın demokrasi teşviki ayağı ele alınmaktadır. AB'nin Ermenistan ile kurumsal ilişkileri demokrasi teşviki bağlamında tarihsel olarak 
Fulya Akgül Durakçay, Özge Bozkaya, “Avrupa Komşuluk Politikası’nda Demokrasi Teșviki: Ermenistan Örneği ve İç Dinamiklerin Değerlendirilmesi”, İstanbul Gelişim Üniversitesi Sosyal Bilimler Dergisi, 6 (2), Ekim 2019, ss. 223-247.

incelenerek AB'nin koşulluluk ve sosyalleşme mekânizmalarına ne ölçüde başvurduğu analiz edilmektedir. Sonrasında ise, Ermenistan'ın iç dinamikleri göz önünde bulundurularak AB'nin demokrasi teşvikinin önündeki engellerin bir değerlendirmesi yapılmaktadır. Bu kapsamda, AB'nin demokrasi teşviki aracılığı ile Ermenistan'da yaratması beklenen etkide ne derece yeterli olup olamayacağı sorusuna iç dinamikler temelinde bir yanıt aranmaktadır. Belirleyici iç dinamikler olarak Ermenistan'ın kurumsal yapısı, geleneksel yönetim anlayıșı, sivil toplumun gelişmesinin önündeki engeller ve ülkenin siyasi, iktisadi ve sosyal yapısı üzerinde hissedilen Rusya nüfuzu ele alınmaktadır.

\section{Avrupa Birliği'nin Demokrasi Teşviki Politikalarının Temelleri}

Soğuk Savaș'ın sona ermesi ile birlikte demokrasiye geçiș sürecine bașlayan ülkelerin sayısının artması ve Batı'daki devletlerin ve uluslararası örgütlerin demokrasinin teșviki, korunması ve tesisini dıș politika gündemlerine almaları ile demokrasiyi teşvik eden devlet ve uluslararası kuruluşlar uluslararası siyasette ön plana çıkmaya başlamıştır. Böylelikle, 1970'li ve 1980'li yıllarda demokratikleşmenin ulusal koşullara bağlı olduğunu ve otoriter rejimlerden demokrasiye geçişte ulusal güçlerin, aktörlerin ve hesaplamaların belirleyici olduğunu dile getiren hâkim görüșe alternatif görüşler çıkmaya başlamıştır (Tolstrup, 2014, s. 4). Tolstup, Pridham'ın 1991 yllında "demokrasiye geçiş çalıșmalarında uluslararası boyutun unutulan ve ihmal edilen unsur" olduğu tespitinin doğruluğunu vurgulamaktadır. 1990'lı yıllardan itibaren demokrasiye geçişte uluslararası faktörlerin de iç faktörler kadar önemli olabileceğini dile getiren görüşler artarak literatürde önemli bir yer edinmiștir.

AB 1990'lı yılların bașından itibaren uyguladığı politikalara demokrasi boyutunu ekleyerek demokrasiyi teşvik eden bir aktör rolünü üstlenmiștir. AB, 1993 yılında yürürlüğe giren Maastricht Antlaşması -Avrupa Birliği Antlaşması- ile demokrasi, hukukun üstünlüğü, insan hakları ve temel özgürlüklere saygının geliştirilmesini ve yerleștirilmesini Ortak Dış ve Güvenlik Politikası'nın (ODGP) bir amacı haline getirmiștir (Official Journal of European Communities, 1992). Antlaşma'nın 2012 yılında yayımlanan konsolide metninin 2. maddesinde Birliğin kurucu değerleri "insan onuruna saygı, özgürlük, demokrasi, eşitlik, hukukun üstünlüğü ve azınlıklara mensup kişilerin hakları da dâhil olmak üzere insan haklarına saygı" șeklinde belirtilmekte; 21. madde ile AB'nin uluslararası alanda kuruluș, gelişim ve genișlemesinin üzerine kurulu olduğu değerlere göre hareket etmesi ve bu değerleri geliștirmesi gerektiği üzerinde durulmaktadır (Official Journal of European Union, 2012). Avrupa Komisyonu 1995 yılında AB'nin üçüncü ülkeler ile sözleșme yolu ile kurduğu ilişkilerde "demokratik prensip ve insan haklarına saygının" yer almasına yönelik yayımladığı tebliğ ile AB dış ilişkilerinde demokrasiye daha fazla yer ayırmaya başlamıștır. Komisyon demokrasi ve insan haklarına saygıyı "vazgeçilmez unsur" olarak tanımlamıștır (Commission of the European Communities, 1995).

AB'nin en başarılı dış politika aracı olarak kabul edilen genişleme politikası kapsamında demokrasi teşvikine bakıldığında, demokrasi ile ilgili koşullara İspanya, Portekiz ve Yunanistan genişlemesi ile yer vermeye başladığı görülmektedir. Böylelikle, $\mathrm{AB}$ aday ülkelerin demokratik performanslarını koşulluluk-uyum çerçevesinde değerlendirmeye başlamıştır (Özkurt, 2017, s. 5). AB bu genişlemesinde bir demokrasi tanımı yapmamış, demokrasiyi üyeliğin genel koșulu olarak belirleyerek, bunun altına özgür ve adil seçimlerin gerçekleştirilmesini, demokratik anayasaların ve siyasi partilerin varlığını dâhil etmiştir. (Erdenir, 2012, s. 98). 1993 yılında gerçekleștirilen AB Konseyi Kopenhag Zirvesi'nde $A B$ üyeliğinin önüne siyasal ve ekonomik koşullar getirilmiştir. Sovyetler Birliği'nin dağılması ile entegrasyon gündemine aldığı ve Merkezi ve Doğu Avrupa (MDA) ülkeleri olarak tanımladığı ülkelerin -Bulgaristan, Çek Cumhuriyeti, 
Fulya Akgül Durakçay, Özge Bozkaya, “Avrupa Komşuluk Politikası’nda Demokrasi Teșviki: Ermenistan Örneği ve İç Dinamiklerin Değerlendirilmesi”, İstanbul Gelişim Üniversitesi Sosyal Bilimler Dergisi, 6 (2), Ekim 2019, ss. 223-247.

Estonya, Letonya, Litvanya, Macaristan, Polonya, Romanya, Slovakya ve Slovenya- adaylık süreci ile başlayarak genişleme politikasında bu kriterler uygulanmıştır. Kopenhag kriterleri çerçevesinde aday ülkelere "demokrasiyi, hukukun üstünlüğünü, insan hakları ve azınlık haklarına saygıyı ve korumayı garanti eden kurumların istikrarını sağlamış olmak" yükümlülüğünü getirmiștir (European Council in Copenhagen, 1993, s. 13).

AB demokrasinin sınırlı ve tek bir tanımını yapmamaktadır. AB Konseyi, 2009 yılı toplantısında demokrasinin dıșarıdan empoze edilemeyeceğini ancak demokratikleșme süreçlerinin her bir ülkenin iç dinamikleri göz önünde bulundurularak çeşitli finansal ve siyasi araçlar ile desteklenebileceğini bildirmiştir. Demokrasiyi insan haklarına saygı, yoksulluğun azaltılması ve kalkınma ile birlikte ele alan $\mathrm{AB}$, demokrasinin evrensel bir değer olarak vazgeçilmez unsurlarının hesap verilebilirlik ve meşruiyet olduğunun altını çizmektedir (Council of the European Union, 2009, s. 1-3). 2009 yılında yürürlüğe giren Lizbon Antlaşması demokrasiyi AB'nin kuruluşunun ve tüm dış ilișkilerinin temeli olarak tanımlamaktadır. Carothers (2009, s. 5), AB'nin demokrasi yaklaşımının seçimleri ve siyasi özgürlükleri temeline alan siyasi yaklaşımın ötesine geçtiğini ve kalkınmaya dayalı demokrasi yaklaşımı ile birleștiğini belirtmektedir. Demokratikleşmeyi uzun vadeli bir süreç olarak ele alan bu yaklașımda siyasi unsurların yanı sıra, sosyo-ekonomik gereklilikler belirleyici olmaktadır. AB'nin demokrasi ve insan hakları teşvikinde kullandığı araçlar siyasi ve sivil özgürlüklerin ötesinde sosyal ve ekonomik özgürlüklerin iyileştirilmesine odaklanmaktadır (Carothers, 2009, s. 16).

1970'li yılların başında Duchêne (1973, s. 19) tarafından "sivil güç" olarak adlandırılan AB, 2000'li yılların başında Manners (2000) tarafından demokrasi ve insan hakları temelinde değer ve normlara yaptığı vurgu sebebi ile "normatif güç" olarak adlandırılmıştır. AB'nin özellikle 2004 yılındaki MDA genişlemesi ile bu ülkelerin demokratikleşmesinde itici bir rol oynaması, AB'nin genişleme politikasında bir "dönüștürücü güç" olarak anılmasını sağlamıștır (Leonard, 2005; Grabbe, 2006; Börzel \& Lebanidze, 2017). Pridham (1999, s. 62) AB'nin demokratik değerleri üyeliğin önünde bir koşul olarak sunması ile ülkelerin demokratikleşme süreçlerinde hayati bir rol oynamasının kendisini "sembolik bir referans noktası" ve "etik destek kaynağı" yaptığını ifade etmektedir. 2012 yılında Nobel Barıș Ödülü'nü kazanan AB'nin genișleme politikası en bașarılı dıș politikası olarak görülmektedir. Bu politika ile AB'nin "Avrupa'nın çoğunu savaş kıtasından barıș kıtasına" dönüștürmedeki rolü vurgulanmaktadır (Avery, 2015, s. 174). Eriş (2012, s. 244) genișleme sürecinde AB'nin normlarını yayması ve kurumsallașma yolu ile güven inșa etmesinin 1945 sonrası yarattığı güvenlik topluluğunu genișletmesi anlamına geldiğini dile getirmektedir.

AB'nin kurumsallaşma ve norm transferi yolu ile üye, aday ve üçüncü ülkelerdeki etkisi literatürde Avrupalılaşma kavramı ile karşılık bulmaktadır. Radaelli, Avrupalılaşma'yı "AB politika yapım süreci içinde oluşturularak, devletlerin ulusal söylem, siyasi yapı ve siyasetlerine entegre ettikleri resmi ve resmi olmayan kurallar, süreçler, politikalar, paradigmalar, tarzlar ve iş yapılış biçimlerinin oluşturulması, yayılması ve kurumsallaştırılması" olarak tanımlamaktadır (Yazgan, 2012, s. 124). Balkır ve Soyaltın (2018, s. 1) Avrupalılaşmanın; AB'nin genişleme kararı ile birlikte Doğu Avrupa'ya kaydığını ve böylelikle aday ülkelerde liberal demokrasi prensibi doğrultusunda reformların yapılmasında $\mathrm{AB}$ etkisinin kayda değer olduğunu dile getirmektedir.

Kelley (2004, s. 7) uluslararası örgütlerin/kurumların demokrasi teşviki politikalarında demokratikleștirilmesi hedeflenen devletin davranıșını değiștirmeye yönelik kullandıkları iki mekânizmanın varlığını dile getirmektedir: koşulluluk ve normatif baskı. Koşulluluk mekânizması ile uluslararası aktörler devlet davranışını teşvik ve yaptırım yoluyla değiștirmeye çalıșırken; normatif baskı mekânizmasında somut teşviklerden ziyade normların ikna etme, ayıplama ya da övgü yoluyla kullanılması ile devlet davranışının değiștirilmesi söz konusu olmaktadır. AB’nin özellikle genişleme 
Fulya Akgül Durakçay, Özge Bozkaya, “Avrupa Komşuluk Politikası’nda Demokrasi Teșviki: Ermenistan Örneği ve İç Dinamiklerin Değerlendirilmesi”, İstanbul Gelişim Üniversitesi Sosyal Bilimler Dergisi, 6 (2), Ekim 2019, ss. 223-247.

politikasındaki demokrasi teşviki başarısı büyük oranda koşulluluk mekânizmasına atfedilmektedir. Schimmelfennig ve Sedelmeier (2002, s. 503) genișlemeyi “örgütsel kural ve normların kademeli ve yasal olarak yatay kurumsallaşma süreci" olarak tanımlamaktadır. Sedelmeier (2011, s. 17), AB'nin aday ülkelerde üyelik baskısını koşulluluk stratejisi ile birleştirerek AB norm ve standartlarının yayılmasını sağladığını tespit etmektedir. Böylelikle, AB'nin ülkelerin içyapılarındaki, kurallarındaki ve davranışlarındaki etkisi norm temelli dış teşvik modeline dayanmaktadır (Eriş, 2012, s. 245).

Schimmelfennig, Engert ve Knobel (2003, s. 495-496) AB'nin demokrasi ve insan hakları prensiplerini teșvikte temel stratejisinin "demokratik koşulluluk" olduğunu ve bu koşulluluğu "pozitif koşulluluk" olarak uyguladığını belirtmektedir. Pozitif koşulluluk; ödüllerin verilmesini -üyelik, kurumsal ilişkilerin güçlendirilmesi, iç pazara erişim, vize serbestisi ve finansal yardım gibi- demokrasiye geçiş ve demokrasinin yerleşmesi için talep edilen reformların gerçekleştirilmesine bağlamaktadır. Reformların gerçekleștirilmemesi durumunda ise ödül esirgenmekte, temel strateji "ödül yoluyla güçlendirme" olarak uygulanmaktadır. Negatif koşullulukta ise, demokrasi ve insan hakları ihlalleri ticari ilişkilerin ve finansal yardımların kesilmesi ya da diplomatik ilişkilerin askıya alınması ve kınama gibi (Eylemer, 2010, s. 28) ceza ya da yaptırım ile karşllık görebilmektedir (Veebel, 2009, s. 208).

Smith (2011, s. 1) özellikle üyelik vaadinin yokluğunda, AB'nin komşuluk alanında normatif dönüşümü sağlayacak mekânizmanın sosyalleşme olduğunu savunmaktadır. Sosyalleșme; temel olarak bir topluluğa ait norm ve kuralların karşı tarafın aktörlerine geçirildiği bir süreç olarak tanımlanmakta ve sonucunda aktörlerin yeni normları içselleştirerek uyum göstermeleri beklenmektedir (Checkel, 2006, s. 804). Risse ve Sikkink (1999, s. 5) sosyalleşmeyi uluslararası normların içselleștirilmesi ve ülke içinde uygulanması süreci olarak tanımlamaktadır. Schimmelfennig (2005, s. 828-830) ise sosyalleşme sürecine rasyonel yaklaşımdan bakarak aktörlerin stratejik hesaplarının sosyalleşme sürecindeki temel belirleyici olduğunu dile getirmektedir. Böylelikle, sosyalleșme norm değişikliği yaratmak için tek başına yeterli olmamaktadır. Bu bağlamda, maliyet-fayda analizlerine ya da güç odaklı siyasi tercihlerine göre hareket eden aktörlerin davranışlarında uluslararası normlara uyup uymamaları bu normları davranışlarına kaynak olarak gösterip gösterememelerine ya da normlara uymamanın yaratacağı maliyete göre belirlenmektedir.

Avrupalılaşma ve demokrasi teşviki çerçevesinde $A B$; hem koşulluluk, hem de sosyalleșme mekânizmalarına başvurmaktadır. AB; Latin Amerika ve Güney Avrupa'da 1970'li yılların ortalarında başlayan üçüncü demokrasi dalgası itibariyle demokratik geçiş süreçlerini desteklemiş ve demokrasi teşvikinde bağıntı siyasetine (linkage politics) başvurmuştur. Bağıntı siyasetine dayalı demokrasi teşviki modelinde temel yöntem demokratikleşmeyi aşağıdan yukarı bir süreçle yürütmeleri için hükümet dışı aktörlerin güçlendirilmesidir. Bu hususta, ulusașırı bağıntılar kurularak sosyalleşme mekânizması ön plana çıkarılmaktadır. Hedef ülkede demokratikleşmeyi savunan sivil toplum ve/veya siyasi aktörler / partiler / gruplar doğrudan desteklenmektedir (Lavenex \& Schimmelfennig, 2011, s. 886-891). AB demokratikleşmesi hedeflenen ülkedeki hükümet ve sivil toplum örgütleri, üniversiteler, bilim kuruluşları ve özel sektör birimleri gibi hükümet dişı aktörler ile etkileșime geçerek sosyalleșme yolu ile kendi norm, kural ve değerlerinin transferini hedeflemektedir (Balkır \& Soyaltın, 2018, s. 77-78). Ayrıca, dolaylı bir yöntem olarak, demokratikleşmenin sosyo-ekonomik gerekliliklerini yerine getirebilmesi için ticaret, yatırım ve finansal yardımlar aracılığı ile hedef ülkenin kalkınmasına destekte bulunmaktadır (Lavenex \& Schimmelfennig, 2011, s. 891). Levitsky ve Way (2005, s.21-25) bağıntıyı bir ülkenin dış aktör ile olan bağlarının yoğunluğu olarak tanımlamaktadır. Bu bağlamda, demokrasi teşvikinin başarısı dış aktör 
ile hedef ülke arasındaki coğrafi, ekonomik, toplumsal, iletişimsel ve ulusaşırı sivil toplum bağıntılarına bağlı kalmaktadır.

Soğuk Savaş'ın sona ermesi ile birlikte yakın komşularında demokratikleşme hareketlerinin yoğunluk kazanması ve birçok Avrupa ülkesinin Birlik'e katılım istek ve niyetlerini açılamaları ile $\mathrm{AB}$, demokrasi teşviki politikalarında koşulluluk mekânizmasını bir kaldıraç (leverage) olarak kullanmaya başlamıştır. Kaldıraç; demokratikleşme için dış baskı olarak tanımlanabileceği gibi (Baracani, 2010, s. 307), otoriter hükümetlerin demokrasi teşviki politikalarını sürdüren dış aktör karşısındaki kırılganlıkları ya da hassasiyetleri olarak da tanımlanabilmektedir (Levitsky \& Way, 2005, s. 21). Koşulluluk mekânizmasının bir kaldıraç olarak başarısı dış aktör ile hedef ülke arasında dış aktör lehine asimetrik bir karşılıklı bağımlılık ilişkisinin bulunmasına bağlıdır. Ayrıca, dış aktör açısından demokrasi teşviki ile çatışan başka bir diş politika önceliği bulunmaması gerekmektedir (Levitsky \& Way, 2005, s. 21-22). Hedef ülke açısından ise karar alıcı aktörlerin dış aktörün kural, norm, davranış ya da politika değișimi taleplerini yerine getirmeleri için rasyonel aktör modeli çerçevesinde teșvikler ile yaptırımların fayda-maliyet analizinin yapılmasını beraberinde getirmektedir (Kubicek, 2003, s. 17). Bu hususta, demokrasi teşvikinin başarılı olabilmesi için AB'nin demokratik reformların gerçekleştirilmesine koșul olarak sunduğu ödüllerin, ülke içi uyum maliyetlerden yüksek olması beklenmektedir (Schimmelfennig \& Sedelmeier, 2004, s. 672-673). Kaldıraç modelinin başarısının bağlı olduğu bir diğer unsur ise hedef ülke kimlik, norm ve değerlerinin $\mathrm{AB}$ kimlik, norm ve değerleri ile özdeșleșme düzeyidir. Yüksek özdeșleşme düzeyi dış aktörün demokrasi teşviki başarısını etkilemektedir (Sedelmeier, 2011, s. 16).

\section{Avrupa Komşuluk Politikası ve Doğu Ortaklığı Çerçevesinde AB'nin Demokrasi Teşviki}

AB'nin MDA genişlemesi ile birlikte sınırları ve komşuları değişmiştir. AB'nin komşularına yönelik tarihsel yaklaşımı AB norm, kural ve koșulları ile uyum sağladıkları müddetçe üçüncü ülkelere üyelik perspektifinin açı tutulması olmuştur. Ancak, bu genişleme ile birlikte AB'nin "genişleme yorgunu" olduğuna, genişlemenin sınırlılığına ve "hazmetme kapasitesinin" varlığına yönelik söylemler ortaya çıkmıştır (Yazgan, 2015, s. 250). Yeni komşuların siyasi, iktisadi ve toplumsal yapıları ile demokrasi, insan hakları ve hukukun üstünlügü alanlarındaki durumlarının $\mathrm{AB}$ düzeyinin oldukça altında olması $\mathrm{AB}$ için muhtemel güvenlik sorunlarını gündeme getirmiştir (Hürsoy \& Kutlu, 2018, s. 170). AB'nin yeni komşularında istikrarı sağlama ihtiyacı (Smith, 2005, s. 758) Birliğin komşularına yönelik genișleme dışında yeni bir politika geliștirmesini gerektirmiștir.

AB'nin ilk olarak 2002 yılında ortaya attığı ve yalnızca Doğu Avrupa komşularına yönelik "Geniș Avrupa" fikri (Council of the European Union, 2012) dönemin Avrupa Komisyonu Başkanı Romano Prodi tarafından "kurumlar dışındaki her şey" ve "ortaklıktan fazlası ve üyelikten azı" olarak tanımlanmıştır (European Commission, 2002). Avrupa Komisyonu'nun 2003 yılında yayımladığı “Geniş Avrupa - Komşuluk: Doğu ve Güney Komşularımız ile İlişkilerde Yeni Bir Çerçeve” başlıklı belgede AB'nin etrafında bir "dostlar halkası" kurma niyeti açıklanmıştır (Commission of the European Communities, 2003, s. 4). AB'nin bu niyeti; hem Birliğe yeni katılan üyelerin varlığı ile çeşitlenen kimlik, çıkar ve ihtiyaçlarına cevap verebilen bir politika, hem de üyelik perspektifi verilmesi düşünülmeyen ülkelerin $A B^{\prime}$ 'den beklentilerini karşılamaya yönelik bir politika oluşturma çabası ile iç içedir (Hatipoğlu, 2004, s. 222).

AB 2003 yılında aynı zamanda ilk kez Avrupa Güvenlik Stratejisi'ni (AGS) yayımlamış ve bu belgede Soğuk Savaş sonrası dönemde güvenliğin iç ve dış boyutlarının birbiri ile bağlantısına vurgu yapmıştır. Terörizm, kitle imha silahlarının 
Fulya Akgül Durakçay, Özge Bozkaya, “Avrupa Komşuluk Politikası’nda Demokrasi Teşviki: Ermenistan Örneği ve İç Dinamiklerin Değerlendirilmesi”, İstanbul Gelişim Üniversitesi Sosyal Bilimler Dergisi, 6 (2), Ekim 2019, ss. 223-247.

yaygınlaştırılması, bölgesel çatışmalar ve organize suçlar güvenlik tehditleri olarak belirlenmiștir. Belgede "hukukun üstünlüğü ve demokrasinin yayılmasının otoriter rejimlerin güvenli, istikrarlı ve dinamik demokrasilere dönüşümünü getirdiğiı" vurgulanarak güvenlik ile demokrasi arasındaki bağlantıya değinilmiștir. AB'nin kendi güvenliği, değerlerinin teșviki ile birlikte ele alınmaktadır. Nitekim AGS'de güvenliği sağlamanın en iyi yolunun iyi yönetilen demokratik devletlerin yer aldığı bir dünya olduğu belirtilmektedir. Ayrıca, komşuluk bölgesinde güvenliğin inşa edilmesi AB'nin stratejik hedeflerinden biri olarak ilan edilmiștir (European External Action Service Strategic Planning, 2003, s. 2-8).

2004 yılında Avrupa Komisyonu'nun yayımladı̆̆ Avrupa Komşuluk Strateji Belgesi ile AB'nin 16 komşusuna yönelik -Doğu'da Azerbaycan, Belarus, Ermenistan, Gürcistan, Moldova ve Ukrayna ile Güney'de Cezayir, Fas, Filistin, İsrail, Libya, Lübnan, Mısır, Suriye, Tunus ve Ürdün- Avrupa Komșuluk Politikası bașlatılmıștır. AB Komșuluk Politikası'nın amacını hem kendisinin, hem komșularının refah, istikrar ve güvenliğini artırmak olarak belirlemiştir (Commission of the European Communities, 2004). Avrupa Komşuluk Politikası'nın temel değerleri demokrasi, hukukun üstünlüğü, insan haklarına saygı, piyasa ekonomisi prensipleri, iyi yönetișim ve sürdürülebilir kalkınma olarak bildirilmiştir (Kahraman, 2005, s. 2).

Arap Baharı ve Suriye krizinin etkisi ile Güney komșularında yaşanan beklenmedik değişiklikleri yönetmek için AB 2011 yılında Komşuluk Politikası'nı revize etmiștir (Dandashly, 2018, s. 65). AB, Güney komşularındaki demokratik geçişi daha aktif olarak desteklemek istediğini göstermek için "Güney Akdeniz ile Demokrasi ve Refah Paylaşımı için Ortaklık" bildirisi yayımlamıștır. Bu ortaklık altında ele alınacak işbirliği alanları demokrasi, insan hakları, sosyal adalet, iyi yönetişim ve hukukun üstünlüğü olarak belirlenmiștir (European Commission, 2011a, s. 2). Revize edilmiş Komşuluk Politikası'nda AB, komşularında sınırlı etki yarattığını kabul ederek (European Commission, 2011b) “derin ve sürdürülebilir demokrasi” anlayışını dile getirmiștir. Derin ve sürdürülebilir demokrasinin unsurları ise şu şekilde sıralanmaktadır: özgür ve adil seçimler, ifade özgürlüğü, toplantı ve dernek kurma özgürlüğü, basın ve medya özgürlüğü, yargının bağımsızlığı ve hukukun üstünlügü̈, yolsuzlukla mücadele ile ordu üzerinde demokratik denetim (European Parliament, 2017).

2015 yılında bir kez daha revize edilen Komşuluk Politikası'nda AB, istikrar ve güvenlik vurgusunda bulunarak, istikrarsızlığın temel sebeplerini ortadan kaldırmayı amaç edindiğini bildirmiştir. Bu bağlamda, komşular ile daha güçlü ortaklıklar kurarak yoksulluk, eşitsizlik, zayıf sosyo-ekonomik gelişmişlik düzeyi, yolsuzluk, adaletsizlik ve firsat yoksunluğu ile mücadele edilmesi hedeflenmiştir. Demokrasi, insan hakları ve hukukun üstünlügünü teșvik edeceğine dair taahhüdünü yinelemekle birlikte $A B$, Komşuluk Politikası'nda odağın güvenlik olacağını belirtmiştir. Böylelikle, yeni Komşuluk Politikası'nın belirlediği üç müşterek işbirliği alanı istikrar için iktisadi kalkınma, güvenlik ile göç ve hareketlilik olmuştur (European Commission, 2015). Avrupa Komşuluk Politikası çerçevesinde ikili ilişkilerde güvenlik boyutuna öncelik vereceğinin sinyallerini veren AB, 2016 yılında yayımladığı AB Küresel Stratejisi ile vatandaşlarının menfaatleri ve $A B$ 'nin güvenlik, barış ve refah tesisini etkileyecek terörizm, iktisadi dalgalanma, iklim değişikliği ve enerji güvensizliği gibi güvenlik tehditleri üzerinde durmuştur (European External Action Service, 2016, s. 1-15).

Kelley (2006, s. 30-31) Komşuluk Politikası'nın varoluş sebebinin AB'nin genişleme stratejisi olduğunu ve AB'nin genişleme süreçlerinde insan haklarl, demokrasi ve hukukun üstünlüğüne ilişkin reformları teşvikinden öğrendikleri ile bu politikayı kurguladığını dile getirmektedir. Nitekim AB, genişlemede kullandığı koşulluluk mekânizmasını başarılı bulmakta ve komşuluk alanına da uygulamaktadır. AB talep ettiği reformların gerçekleştirilmesi koşulu ile şu teşvikleri önermektedir: a) iç pazarına 
katılım, b) tercihli ticaret anlaşmaları, c) yardımların artırılması, d) göç ve kişilerin dolaşımının kolaylaştırılması, e) ortak güvenlik tehditlerine karşı genişletilmiş işbirliği, f) çatışma önleme ve kriz yönetiminde AB'nin siyasi rolünün artırılması, g) insan haklarını teşvik ve kültürel işbirliğinin geliștirilmesi h) ulaşım, enerji ve haberleşme ağlarına ve Avrupa Araştırma Alanı'na entegrasyon (Commission of the European Communities, 2003). Dönemin AB Dıșişleri ve Güvenlik Politikası'ndan sorumlu Yüksek Temsilcisi Catherine Aston komşuluk alanında derin ve sürdürülebilir demokrasi görmek için gerekli olduğunu belirttiği bu teşvikleri "para-pazar-hareketlilik" olarak özetlemektedir (European Union, 2011). Ayrıca AB, Komşuluk Politikası'nda "daha fazlası için daha fazlası" (more for more) prensibi ile talep edilen reformların gerçekleştirilmesi durumunda AB'nin ilgili ülkeye desteğini artıracağını belirtmektedir (European Commission, 2014a).

AB Komşuluk Politikası çerçevesinde başlıca finansal araç olarak Avrupa Komşuluk Aracı'nı (ENI) kullanmaktadır. 2014-2020 dönemi için 15,4 milyar avro bütçeye sahip bu araç ile insan hakları, temel özgürlükler, hukukun üstünlügü, demokrasi ve iyi yönetişim ve güçlü sivil toplumun teşvik edilmesi hedeflenmektedir (European Union, 2017). AB, demokrasi teşviki için ayrıca Demokrasi ve İnsan Hakları için Avrupa Aracı'nı (EIDHR) kullanmaktadır. Fonların büyük bir kısmı sivil toplum örgütlerine ve risk altındaki insan hakları savunucularına ayrılırken, seçim yardımları ve AB seçim gözlem misyonlarını desteklemek için de fon ayrılmaktadır. 2014-2020 dönemi için 1,33 milyar avro bütçesi olan bu aracın diğer finansal araçlardan temel farkı hibe için üçüncü ülke hükümetinin iznini gerektirmemesidir (Zamfir, 2018, s. 4).

Komşuluk Politikası'nın oluşturulma aşamasında bu politikanın amacı “AB'nin özünü oluşturan prensipler, değerler ve standartlar bütünün komşuluk bölgesine genişletilmesi" olarak sunulmuştur (European Commission, 2002). AB Komşuluk Politikası çerçevesinde sosyalleşmeyi, koşulluluğu güçlendirici bir strateji olarak kullanmaktadır. Yakın işbirliği ve etkileşim yolu ile hem $A B$, hem komşu ülkeler sosyalleşme sürecine girmektedir (Sasse, 2008). Siyasi diyaloglar, AB yetkilileri ile komşuluk ülkelerinden çeşitli düzeylerdeki yetkililerin arasındaki resmî temaslar, Birlik ile komşuluk ülkeleri arasında oluşturulan ikili eylem planları ve ilerleme raporları AB'nin kullandığı temel sosyalleşme araçları olarak karşımıza çıkmaktadır. Sosyalleşme ile koşulluluğun hükümetlerarası yapısının ötesine geçilerek hükümet dışı aktörler sosyal öğrenme sürecine dâhil edilmektedir (Kelley, 2006, s. 39-40). Balkır ve Soyaltın (2018, s. 78) AB'nin proje hibeleri, eşleştirme projeleri ve eğitim ve değişim programları ile toplumsal düzeyde etki göstermesinin önemli olduğunu ve uzun vadede politik değişimi getirmede koşulluluktan daha başarılı olmasının beklendiğini dile getirmektedir. Ancak, AB'nin taleplerinin meşruiyetinin ve $A B$ kimlik ve değerleri ile ulusal kimlik ve değerlerin özdeşleşme düzeyinin yüksek olmasının belirleyiciliğine dikkat çekmektedir.

AB Komşuluk Politikası'nda kullandığı araçları her ülkenin kendi siyasi, iktisadi ve toplumsal koşullarına uygun olarak kullandığını belirtmekte ve bu yaklaşımını farklılaştırılmış ve esnek olarak tanımlamaktadır (Koenig, 2016, s. 4). Avrupa Komşuluk Politikası'nın oluşturulmaya başlandığı ilk yıllardan itibaren Eylem Planlarının her ülkenin kendi özelliklerinin dikkate alınarak hazırlanması ve komşu ülkelerin reformları gerçekleştirmelerindeki performansları izlemek için bir araç olarak kullanılması bu esnek yaklaşımı gösterir niteliktedir (Hatipoğlu, 2004, s. 226). AB Komşuluk Politikası'nın AB çıkar ve önceliklerinin tek taraflı bir süreçle komşu ülkelere empoze edilmesinin söz konusu olmadığını, sürecin müşterek değerlerin ve ortak çıarların ortak sahiplenmesine dayandığını belirtmektedir (Commission of the European Communities, 2004, s. 8). Böylelikle, demokrasi teşvikinde bir dış aktör olarak AB'nin rolü kadar ilgili devletin iç dinamikleri belirleyici rol oynamaktadır. 
Karadeniz'e kıyısı olan Bulgaristan ve Romanya'nın 2007 yılında AB'ye üyeliği ile $\mathrm{AB}$, Karadeniz bölgesinde yer alan komşularına yönelik daha kapsamlı bir politika oluşturma ihtiyacı hissetmiştir. Karadeniz Sinerjisi ile başlatılan bu yaklaşım, 2008 Rusya-Gürcistan savaşının da etkisi ile Doğu komşularına yönelik farklılaștırılmış bir yaklaşıma duyulan ihtiyaç ile pekiştirilmiștir. Böylelikle $A B$, toprak bütünlüğü ve devlet olma normuna desteğini belirterek Azerbaycan, Belarus, Ermenistan, Gürcistan, Moldova ve Ukrayna'ya yönelik Doğu Ortaklığı Girişimi'ni başlatarak ikili ve bölgesel olarak çok taraflı ilişkileri derinleștirmeyi amaçlamıștır (Commission of the European Communities, 2008, s. 2-4). Doğu Avrupa'da ve Güney Kafkasya'da yaşanan renkli devrimler ve AB yanlısı yönetimlerin başa geçmesi ile Rusya'nın bölgede etkisini artırmak için izlediği politikalar AB'nin bölgede yeni bir bölgesel aktör olarak rolünü pekiștirmesini gerektirmiştir (Gültekin-Punsmann \& Nikolov, 2008, s. 115).

Doğu Ortaklığı kapsamında Birlik; ortaklarının AB yasama, standart ve normları ile yakınlaşmalarını sağlayarak entegrasyonu ilerletmeyi amaçlamıştır (Huff, 2011, s. 12). Siyasi ilişkilerin derinleştirilmesi için Ortaklık Anlaşmalarının (Association Agreements) müzakere edilerek imzalanması ve buna bağlı olarak ekonomik ilişkilerin derinleșmesi için Derin ve Kapsamlı Serbest Ticaret Alanlarının kurulması ile vize kolaylaştırma ve/veya serbestliği demokratik reformların karşllı̆̆ındaki teşvikler olarak önerilmiștir (Council of the European Union, 2009). AB Doğu ortaklarının demokratik ve pazar ekonomisine geçiş odaklı reformları gerçekleştirmeleri için ek ve somut destekler vereceğini belirtmiştir. Doğu Ortaklığı çerçevesinde dört işbirliği alanı belirlenmiş ve bu alanların ilkini demokrasi, iyi yönetişim ve istikrar oluşturmuștur. Diğer alanlar ise ekonomik entegrasyon ve $\mathrm{AB}$ politikaları ile uyum, enerji güvenliği ve hareketlilik ile bireyler arası etkileşimdir. Ortaklık Anlaşmaları için müzakerelere başlanması demokratik koşulluluk ilkesine bağlanarak demokrasi, hukukun üstünlüğü ve insan hakları bağlamında yeterli ilerlemenin kaydedilmesinin gerekliliği ile Avrupa Konseyi, AGIT, Birleşmiş Milletler (BM) tarafından ortaya konan uluslararası standartlara uyulmasının gerekliliği ifade edilmiștir (Commission of the European Communities, 2008, s. 2-4).

Doğu Ortaklığı çerçevesinde ikili ilişkilerin ötesine geçilmesi amaçlanarak çok taraflı etkileşimin öne çıkması ile sosyalleşme mekânizmasına verilen önem artırılmıştır. Bu bağlamda, AB Doğu Ortaklarının en üst düzey yetkilileri arasında düzenli toplantı yapılması yeniliğini getirmiştir. Böylelikle devlet başkanları ya da hükümet başkanları iki yılda bir, dış işleri bakanları ise yılda bir olmak üzere düzenli olarak görüşmektedir. Üst düzey siyasi etkileşime ek olarak Doğu Ortaklığı Sivil Toplum Forumu kurularak ülkeler arası sivil toplum diyaloglarının geliştirilmesi hedeflenmiştir (Council of the European Union, 2009). Avrupa Komşuluk Politikası'nın hükümet odaklı yaklaşımını tamamlayıcı olarak Doğu Ortaklığı çok düzeyli ve çok taraflı yaklaşımı ile EuroNest Parlamenterler Meclisi, Doğu Ortaklığı için Bölgesel ve Yerel Yönetimler Konferansı (CORLEAP) ve İş Forumu oluşturulmuştur (Freire \& Simao, 2013, s. 179).

\section{Teşviki \\ Avrupa Birliği-Ermenistan İlişkilerinin Kurumsal Temelinde Demokrasi}

AB, Sovyetler Birliği'nin dağılması ile sınırlarının dayandığı eski Sovyet Sosyalist ülkeleri ile ilişkilerini iki farklı politika ile düzenlemiștir. Bu politikaların ilki, entegrasyon ve üyelik perspektifinin yer aldığı Merkezi ve Doğu Avrupa ülkeleri olarak tanımladığı ülke grubuna yönelik geliștirilmiștir. Bu ülkelerle PHARE (Poland and Hungary Action for Restructuring of the Economy) finansal yardım aracı ile desteklen Ortaklı Anlaşmaları imzalanmıştır. Estonya, Letonya ve Litvanya bu grupta yer alırken, içlerinde Ermenistan'ın da yer aldığı Sovyetler Birliği'nin dağılması ile bağımsızlıklarına kavuşan 
Fulya Akgül Durakçay, Özge Bozkaya, “Avrupa Komşuluk Politikası’nda Demokrasi Teșviki: Ermenistan Örneği ve İç Dinamiklerin Değerlendirilmesi”, İstanbul Gelişim Üniversitesi Sosyal Bilimler Dergisi, 6 (2), Ekim 2019, ss. 223-247.

diğer ülkeler Yeni Bağımsız Devletler olarak adlandırılmıştır. Yeni Bağımsız Devletler TACIS (Technical Assistance to the Commonwealth of Independent States and Georgia) finansal yardım aracı ile desteklenmiş ve bu devletlerle Ortaklık ve İşbirliği Anlaşmaları imzalanmıștır (Partnership and Co-operation Agreements) (Solonenko, 2009, s. 713).

AB'nin 1990 yılında başlattığı TACIS programının ilk odağı bu programda yer alan ülkelerin ekonomilerinin iyileștirilmesini ve serbest piyasa ekonomilerine geçişlerini sağlamak olmuştur. Kurumsal, yasal ve idari reformların desteklenmesini amaçlayan TACIS programı altında iki çerçeve programına yer verilmiştir. Bu programlardan ilki olan TRACECA (Transport Corridor Europe-Caucasus-Asia) kapsamında kişilerin ulaşımı ve malların taşımacılığı için bu ülkelerin geleneksel rotası olan Moskova yoluna alternatif bir yol sunularak Avrupa üzerinden dünya pazarlarına erişim imkânının sunulması hedeflenmiștir. Diğer program olan INOGATE (Interstate Oil and Gas Transport to Europe) kapsamında ise teknik yardım vasıtasıyla enerji sektörüne özel yatırımın çekilmesi ve bu alandaki taşımacılığın kolaylaştırılması hedeflenmiştir. AB TACIS programı dışında Azerbaycan ve Gürcistan ile birlikte Güney Kafkasya ülkesi olarak değerlendirdiği Ermenistan'a nükleer güvenlik, insani yardım ve gıda yardımına ilişkin programları aracılığı ile serbest piyasa ekonomisine geçiş sürecinden kaynaklanan ihtiyaçlara yönelik desteklerde bulunmuştur. 1992-2000 yılları arasında AB'nin Ermenistan'a yardımı 280,33 milyon avroyu bulmuştur (Demirağ, 2004-2005, s. 92-94). Ancak, bu programlar kapsamındaki ulusal programların çok kapsamlı ve esneklikten uzak oluşu, henüz geçiş aşamasının başlarında olan ülkelerin ihtiyaç ve önceliklerinin göz ardı edildiği yönündeki eleştirilere yol açmıştır (Şahbazov, 2015, s. 112).

AB'nin finansal ve teknik yardım araçlarında demokrasi ile ilgili bir gündem oluşturması ise, Avrupa Parlamentosu'nun 1992 yılı bütçesinde demokrasiye yer verilmesini dile getirmesi ile birlikte Avrupa Komisyonu'nu bu finansal araçlarda bir demokrasi programı içermeye karar vermesi ile gerçekleşmiștir (Olsen, 2000, s. 148). Böylelikle, TACIS Demokrasi Programı çoğulcu demokratik toplumların, hukukun üstünlügünün ve hükümet dişı örgütlerin (non-governmental organisations NGOs) teșvik edilmesini amaç edinmiștir (Braitwaite, Eberhardt \& Johnson, 1998, s. 5). TACIS demokrasinin yerleştirilmesi hususunda bilgi transferi, teknik yardım ve politika belirlemeye yönelik projeleri destekleyen bir araç olarak kullanılmıştır (Efegil, 2008, s. 67).

TACIS Demokrasi Programı kapsamında "Ermenistan'da Parlamento Seçimi" başlıklı proje ile Ermenistan'da ilk çok partili seçimin gerçekleştirildiği 1995 seçimleri için Fransa ve Birleşik Krallık'tan uzmanlar adaylara ve Merkezi Seçim Komisyonu'na yönelik bilgilendirici seminerler vererek, seçim sistemi, oy hakkı, oyların sayımı ve denetimine ilişkin tanıtıcı yayınlar dağıtmıştır. "Ermenistan Parlamento Seçimlerinin Medya Denetimi" başlıklı proje ile seçim sürecinde şeffaflığın artırılması ve 40 gazeteci ve düzenleyiciye yönelik seminer ile medyada mesleki ahlak kurallarının olușturulması amaçlanmıştır (Braithwaite, Eberhardt \& Johnson, 1998, s. 8-16). Ancak, TACIS kapsamında doğrudan demokrasi teşvikine ayrılan bütçelerin oranı ekonominin iyileşmesine ve pazar ekonomisine geçişe yönelik bütçelere nazaran oldukça sınırlı kalmıştır (Olsen, 2000, s. 149). Bu durum, AB'nin demokrasiye kalkınmacı yaklaşımını yansıtarak, istikrar ve güvenliği sağlamada sosyo-ekonomik göstergelere verilen önemi göstermektedir. 1990’lı yıllarda hem Ermenistan ile ilişkileri, hem de Güney Kafkasya'ya yönelik genel politikası ekonomik temelli olan AB; bölgedeki Dağlık Karabağ meselesinin ve Abhazya ve Güney Osetya'daki çatışmaların çözümünde ikincil bir rol üstlenmiştir. Avrupa Güvenlik ve İşbirliği Teşkilatı (AGIT) ve Birleşmiş Milletler (BM)'in çatışmaların çözümüne yönelik çabalarını destekleyici yönde hareket etmiştir (Demirağ, 2004-2005, s. 96). 
AB, Ermenistan ile 1996 yılında Ortaklık ve İşbirliği Anlaşması imzalamış ve bu anlaşma 1999'da yürürlüğe girerek 10 yll geçerli olmak üzere sürenin sonunda kendiliğinden yenilenmiștir. Bu Anlaşma ile ilk kez ekonomik işbirliğinin ötesine geçilerek, siyasi diyalog için bir çerçeve sunulmuştur. Hem üst düzey yetkililer arasında düzenli görüşmelerin yapılmasının, hem de ikili ve çok taraflı platformlarda diplomatik kanallardan yararlanılmasının siyasi diyalogun geliştirilmesine katkı sağlayacağı belirtilmiştir. Taraflar arasında ticari, finansal ve teknolojik işbirliğinin yanı sıra kültürel işbirliğinin geliştirilmesine yer verilmiştir. $\mathrm{AB}$ böylelikle ikili etkileșimin artırılmasını hedefleyerek hem de AB-Ermenistan arasında bağıntı oluşturma yoluna gitmiş, hem de sosyalleşme mekânizmasını kullanmaya başlamıştır.

Anlaşmanın 1. maddesi ticaret, yatırım ve iktisadi ilişkilerin güçlendirilmesinin yanı sıra Ermenistan'ın demokrasiyi yerleştirmek ve pazar ekonomisine geçişi sağlamak için çabalarının desteklenmesine yer vermiştir. Anlaşma, ortaklığın özünü demokrasi, insan hakları ve pazar ekonomisi prensiplerine saygı olarak belirtmiștir. AB demokrasi, hukukun üstünlüğü ve insan haklarına saygı prensiplerini dile getirirken BM Sözleşmesi, Helsinki Nihai Senedi, Yeni Bir Avrupa İçin Paris Şartı (the Charter of Paris for a New Europe) ve AGIT prensiplerine referans vererek demokrasi teşvikinde uluslararası normları pekiştirici bir rol üstlenmiştir. Demokrasi ve insan haklarına ilişkin hususlarda ikili işbirliğinin demokratik kurumların olușturulması ve yerleştirilmesi, hukukun üstünlügünün güçlendirilmesi ve insan hakları ile temel özgürlüklerin korunmasına odaklanacağı belirtilmiştir. Bu husustaki teknik yardım programlarının mevzuatın ve düzenlemelerin oluşturulması, ilgili mevzuatın uygulanması, yargı organının ve seçim sisteminin işlerliğinin sağlanmasına yöneleceği dile getirilmiștir. Tarafların parlamenterleri, yargı organı mensupları ve hükümet dışı örgütleri arasında etkileșimin ve hareketliliğin sağlanmasına yönelik teșviklerde bulunmasının gerekliliği ifade edilmiştir (Official Journal of European Communities, 1999).

Avrupa Komşuluk Politikası'nın kurucu belgelerinde üç Güney Kafkasya ülkesi Ermenistan, Azerbaycan ve Gürcistan "geniș Avrupa" fikrine dâhil edilmemiş iken; 2004 yılında Avrupa Komşuluk Politikası'nın olușturulması aşamasında Avrupa Komisyonu'nun tavsiyesi üzerine bu üç ülke Komşuluk Politikası'na dâhil edilmiştir (Commission of the European Communities, 2004). Böylelikle, AB Güney Kafkasya bölgesini Komşuluk Politikası'nın temel amaçlarından biri olan AB'nin dış sınırlarında güvenlik ve istikrarın sağlanmasının dıșında görmediğini göstermiștir. İyi komşuluk ilişkilerinin geliștirilmesine yaptığı vurgu ile bölgenin istikrarının ve bölgedeki çatışmalarının çözümünün $\mathrm{AB}$ için önemini göstermiştir. Böylelikle $\mathrm{AB}$, hem bu ülkelerin demokratikleșmesinde, hem de çatışmaların çözümünde daha aktif bir rol oynayacağının sinyalini vermiștir (Demirağ, 2004-2005, s. 99). AB'nin bu politika değişiminde bölgedeki enerji kaynaklarının, bölgenin önemli bir ulaşım koridoru olmasının ve AB'nin bölgede ekonomik ve siyasi çıkarları olan ABD ve Rusya'ya alternatif olușturmak istemesinin etkisi olduğunu söylemek mümkündür (Şahbazov, 2015, s. 110-111).

Komşuluk Politikası kapsamında AB ülke temelli Eylem Planları hazırlamıștır. ABErmenistan Eylem Planı'nın (EU/Armenia Action Plan) müzakerelerine 2005 yılında başlanmıștır. Eylem Planı ile işbirliğinin ötesine gidilmesi hedeflenmiștir. Bu hedef doğrultusunda, ekonomik entegrasyon ve siyasi diyalogun geliştirilmesi ile istikrar, güvenlik ve refahın artırılması amaçlanmıştır. İlişkilerin yönünü Ermenistan'ın ortak değerlere bağlılı̆̆ ve üzerinde anlaşılan öncelikleri uygulamadaki ilerlemesinin belirleyeceğini belirten $A B$, pozitif ve demokratik koşulluluk ilkesini uygulayacağını göstermiştir. Eylem Planlarını norm ve kural transferi için bir araç olarak kullanan $A B$; Eylem Planı'nın uygulanması ile Ermenistan'ın AB mevzuat, norm ve standartlarına yakınlaştırılmasını amaçlamıştır (European External Action Service, 2006). AB, Ermenistan ile Eylem Planı'nın oluşturulmasında önceki kurumsal araçlara oranla daha 
esnek davranarak iç dinamikleri daha fazla dikkate almıştır. AB demokrasinin yerleşmesine yaptığı vurguyu artırarak Ermenistan'ın gerçekleștirmesini talep ettiği reformları sunmuştur. $A B$ demokrasi yaklaşımında siyasi ve sivil hakların geliştirilmesini temel almanın yanı sıra, demokratikleșme sürecini sosyo-ekonomik gerekliliklerin iyileștirilmesi ile birlikte ele almaya devam etmiștir. AB ayrıca Eylem Planı ile Ermenistan'ın $\mathrm{AB}$ entegrasyonuna yönelik niyetini tanımış ancak bu tanıma sembolik destek düzeyinde kalmıştır.

Eylem Planı ile ilişkilerin seyrinin işbirliğinden entegrasyona doğru derinleștirilmesi hedeflenerek sekiz öncelikli alan belirlenmiștir. Öncelikli alanlardan ilki doğrudan demokrasinin yerleștirilmesine yöneliktir. Yasama organının reformu ile dolandırıcılık ve yolsuzlukla mücadele dâhil olmak üzere demokratik yapıların ve hukukun üstünlüğünün güçlendirilmesi amacı ile Ermenistan'dan birtakım taleplerde bulunulmuştur. $\mathrm{Bu}$ talepler; güçler ayrılığının ve yargının bağımsızlığının fiilen sağlanması, seçimlerin AGíT standartlarına ve uluslararası standartlara uygun düzenlenmesi, Adalet Konseyi'nin yasama ve yürütmeden bağımsızlığının garanti altına alınması, idari mahkemelerin kurulması, Eylem Planı'nın uygulanmasının izlenmesi ve bu süreçte sivil toplumun katılımının sağlanmasıdır. Öncelikli alanlardan ikincisi Ermenistan'ın uluslararası taahhütlerine uygun olarak insan hakları ve temel özgürlüklere saygının güçlendirilmesidir. Bu hususta $A B$, medyanın bağımsızlığının sağlanması, toplantı yapma özgürlüğünün tesis edilmesi, bireysel mülkiyet hakkının korunması, gözaltı koşullarının iyileştirilerek cezaevleri hukukunun reformu, polis teşkilatında yolsuzluğun önüne geçilmesi ve işkence ile kötü muamelenin ortadan kaldırılması için AGíT ve Avrupa Konseyi ile uluslararası işbirliğine gidilmesi ile ilgili reform taleplerinde bulunmuştur. Diğer öncelikli alanlar AB'nin sürdürülebilir kalkınma hedeflerine yönelik talepleri içererek ekonomik entegrasyonun derinleștirilmesi için yoksulluğun azaltılması, sosyal uyumun güçlendirilmesi, çevrenin korunması, AB enerji politikasının amaçları ile uyumlu bir enerji stratejisinin uygulanması, Dağlık Karabağ meselesinin barışçl çözümü için siyasi ve diplomatik çabaların artırılmasını ve bölgesel ișbirliğinin geliştirilmesini içermiștir (European External Action Service, 2006).

$\mathrm{AB}$, Ermenistan ile ilişkilerini Doğu Ortaklığl Girişimi çerçevesinde derinleștirmektedir. Doğu Ortaklığı Girişimi kapsamında AB, Ermenistan ile Derin ve Kapsamlı Serbest Ticaret Alanını içeren Ortaklık Anlaşması müzakerelerini tamamlamış ve 2013 Vilnius Zirvesi'nde müzakerelere başlanmasını planlamıştır. Ancak, Ermenistan Anlaşma'yı imzalamama kararını bildirerek Rusya, Belarus ve Kazakistan'ın yer aldığı Avrasya Gümrük Birliği'ne katılacağını açıklamıştır. Aynı yıl, Ermenistan ile vize kolaylığı ve geri kabul anlaşmaları imzalanmıș ve bu anlașmalar 2014 yılında yürürlüğe girmiștir. (European Commission, 2014b, s. 2). Ermenistan'ın 2 Ocak 2015'te Avrasya Gümrük Birliği'ni kapsayan Avrasya Ekonomik Birliği'ne üye olması ile birlikte AB ikili ilişkilerini Ermenistan'ın bu üyeliğinden doğan yükümlülükleri ile uyumlu olacak ş̧ekilde sürdürmeye devam etmiştir. Ekim 2015'te AB Ermenistan ile yeni bir anlaşma üzerine müzakerelere başlanacağını duyurmuş ve müzakerelere Aralık ayında başlanmıștır. (European External Action Service, 2016).

Müzakere sürecinin tamamlanması sonucu $\mathrm{AB}$ ile Ermenistan arasında 24 Kasım 2017'de Kapsamlı ve Genişletilmiş Ortaklık Anlaşması imzalanmıştır. Bu Anlaşma ile AB, Güney Kafkasya'daki siyasi ve iktisadi varlığını artırdığını belirtmiştir. Anlaşmanın hedefleri arasında Ermenistan'ın AB politikalarına ve programlarına katılımını artırarak siyasi ve iktisadi ișbirliğini ve ortaklığı geliștirmek, Ermenistan'da demokrasinin ve siyasi, iktisadi ve kurumsal istikranın güçlendirilmesine katkıda bulunmak, sınır ötesi işbirliğini ve sınır güvenliğini artırarak iyi komşuluk ilişkilerini güçlendirmek, hukukun üstünlüğü, insan haklarına ve temel özgürlüklere saygı esasında özgürlük, güvenlik ve adalet alanındaki ilişkileri güçlendirmek, kişiler arası etkileşimi artırmak, ticari ilişkileri 
geliştirmek ve Ermenistan mevzuatının $\mathrm{AB}$ mevzuatına yakınlaştırılmasını desteklemek yer almaktadır. AB reformların șu alanlarda olması gerektiğini belirtmiştir: demokratik kurumların ve hukukun üstünlüğünün yerleştirilmesi ve istikrarlılı̆̆l ile etkinliğinin sağlanması, insan hakları ve temel özgürlüklere saygının garanti altına alınması, yargının, yasal takibatın ve yasaların uygulanmasının bağımsızlığını temin edecek adli ve hukuki reformlarda ilerleme kaydedilmesi, kamu hizmetinin hesap verilebilirlik ve şeffaflık ilkeleri çerçevesinde reformu ve yolsuzlukla mücadelede etkililiğin sağlanması. AB ayrıca demokratik reformlar ile ekonomik gelişme, sürdürülebilir kalkınma, istikrar ve sorunların barışçıl yollarla çözülmesi arasındaki bağa işaret etmiştir (European Commission, 2017).

AB'nin 2014'ten bu yana iktisadi kalkınma, inovasyon ve kişisel gelişim, hukukun üstünlügü prensibinin geliştirilmesi, seçim desteği gibi alanlarda Ermenistan'a finansal desteği 120 milyon avroya yaklaşmıștır (European External Action Service, 2018). AB, Doğu Ortaklığı kapsamında $A B$ demokratik norm ve kurallarının aktarımında siyasi aktörler, sivil toplum ve bireyler arasındaki etkileşimin ve sosyal öğrenmenin etkisine verdiği önemi artmıștır. Bu hususta, parti politikalarının zayıf olduğu Ermenistan'da siyasi partilerin Avrupa Parlamentosu ile etkileşimi Doğu Ortaklığı kapsamında gittikçe artmaktadır. EuroNest Parlamenterler Meclisi; Ermenistan'dan 10 parlamenter, Belarus dışındaki diğer Doğu Ortaklığı ülkelerinden parlamenterler ve Avrupa Parlamentosu'ndan 60 parlamenter ile bir araya getirmekte ve ülke parlamenterlerinin AB mevkidaşları ile sosyalleşmelerini kolaylaştırmaktadır (Kostanyan \& Vandecasteele 2013, s. 5-8). AB, Ermenistan'da sivil toplumun gelişimini hem demokratikleşmenin bir aracı olarak gördüğü için desteklemekte, hem de sivil topluma reformların gerçekleştirilmesini denetleyici bir misyon yüklemektedir. Doğu Ortaklığı Sivil Toplum Forumu aracılı̆̆ı ile Ermenistan sivil toplumunun Doğu Ortaklığı'nda yer alan diğer ülkelerin sivil toplumları ile diyalogunun kolaylaştırılması sağlanarak, etkileşimleri ve sosyalleşmeleri artırılmaktadır. Sosyalleşmenin bir diğer aracı; Ermenistan'da vize kolaylığı, öğrenci ve akademik personel değișim programları aracılığı ile uygulanmaktadır. 2015-17 yılları arasında Erasmus+ programından 1300 öğrenci ve akademik personel, eșleștirme (eTwinning Plus) programlarından ise 70 okul yararlanmiştır (European External Action Service).

AB, Ermenistan'a yönelik demokrasi teşviki politikalarında demokratik koşulluluk ilkesini tutarlı uygulamadığı yönünde eleștirilmektedir. Börzel ve Lebanidze (2017, s. 20) AB'nin Ermenistan'da 2003 yılından beri yapılan seçimlerin sonuçlarının ihtilaflı bulunmasına rağmen eleștirilerini sınırlı tuttuğuna ve finansal ve teknik yardımları siyasi reformların gerçekleșmesi koşuluna bağlamadığına dikkat çekmektedir. AB, 2008 seçimlerini takip eden protestolar sırasında yaşanan tutuklamalar, yaralanmalar ve 10 kişinin hayatını kaybetmesi ile sonuçlanan seçim sonrası şiddete yönelik duyduğu endişeyi dile getirmiştir. AB, Ermenistan'dan toplantı ve gösteri yapma hakkına saygı göstererek hukuksuz tutuklanmalara son vermesini isteyerek bağımsız bir soruşturmanın yürütülmesini vurgulamıştır (Council of the European Union, 2008).

2008 seçimleri sonrasında $A B$, demokrasi teşviki kapsamında seçim izleme sürecine verdiği önemi artırmıştır. AGíT ile birlikte 2012 parlamento ve 2013 başkanlık seçimlerini izlemek için 1,7 milyon avro harcayarak seçim komisyonunun ve polis teşkilatının kurumsal yapısını güçlendirmeyi, insan haklarının korunmasını artırmayı ve sivil toplumun seçim sürecindeki rolünü güçlendirmeyi amaçlamıştır (Armenpress, 2012). AB, 2012 ve 2013 seçimlerini șeffaflık ve rekabete dayanması açısından bir ilerleme olarak değerlendirmekle birlikte tüm siyasi aktörleri hukuksuz davranışlardan kaçınmaya davet ederek muhalefetle kurulacak siyasi diyalogun önemini vurgulamış (European Union, 2012) ve seçimlerin uluslararası standartlar düzeyinde gerçekleştirilmesi için eksikliklerin devam ettiğini dile getirerek kamu personelinin 
tarafgirliğini, vatandaşlar üzerinde kurulan baskıyı ve kaynakların kötüye kullanımını eleştirmiştir (European Commission, 2013).

$\mathrm{AB}$ Ermenistan'ın özellikle yargı sisteminin, hukukun üstünlüğünün ve insan haklarının korunmasına yönelik reformları gerçekleștirmesini beklemektedir (Kostanyan, 2015, s. 140). AB'nin demokratikleşme ve çatışma çözümü konusundaki beklentileri $\mathrm{AB}$ ile ilişkilerini ekonomik çıarları temelinde geliştirmek isteten Ermenistan'da yeterince karşılık bulamamaktadır (Simao, 2012, s. 197). Ancak, Ermenistan'da insan hakları ve hukukun üstünlüğü ihlalleri ile demokratikleşmenin beklenenin altında kalmasında rağmen (Freire \& Simao, 2013, s. 6), AB'nin Ermenistan ile ticari ilişkilerini geliştirdiği ve derinleștirdiği görülmektedir. AB'nin koşulluluk mekânizmasını seçici ve tutarsız uygulamasının ise Ermenistan'daki otoriter rejimin sağlamlașmasına katkıda bulunduğunu gündeme getirmektedir (Börzel \& Lebanidze, 2017, s. 20).

\section{Ermenistan'daki Demokrasi Teşvikinin İç Dinamikler Bağlamında Değerlendirilmesi}

$\mathrm{AB}$ demokrasi teşviki, iki yönlü bir sürece işaret etmektedir. Dolayısıyla, AB'nin Ermenistan'daki demokrasi teşvikini, yalnızca Birliğin politika tercihi bağlamında analiz etmek yetersiz kalmaktadır. Buna göre, Ermenistan'daki iç dinamikleri göz önünde bulundurarak kurumsallaşma yönünde Ermenistan'ın girişimleri, siyasi elitlerin yaklaşımı ve sivil toplum gibi faktörler bağlamında değerlendirme yapmak, AB'nin Komşuluk Politikası kapsamında ilgili ülkelerin bu teşvike katılım derecesinin önemli bir tamamlayıcısı olduğu konusunda açıklama sunmaktadır. AB'nin koşulluluk ve sosyalleșme mekânizmaları aracılığıyla izlediği demokrasi teşviki politikaları, AB ve Ermenistan arasında karşılıklı etkileşimin öne çıktığı iki taraflı bir katılım sürecini gerektirmektedir (Freire \& Simao, 2013, s. 176-177). Bu sebeple, çalışmanın bu bölümünde, karşılıklı katılım sürecinin önemli bir bileşeni olan Ermenistan'ın iç dinamiklerinin demokrasi teșviki sürecine nasıl etki ettiği tartışılmaktadır.

Sovyetler Birliği'nin dağılması ile birlikte diğer eski Sovyet Sosyalist ülkelerinde olduğu gibi Ermenistan'da da bağımsızlık için mücadele ön planda turularak demokrasiye geçiş, rejim değişikliği sürecinde daha arka planda kalmıştır (Asker, 2010, s. 196). Bu anlamda, Ermenistan'ın Sovyetler Birliği'nden ayrılmasıyla içine girdiği ulusal sistem yaratma süreci, demokratikleşme bağlamında hala bir dönüşüm içerisindedir. Bu süreçte, iç dinamikleri şekillendiren karar alma mekânizmasının çıktıları, bu mekânizmaya sivil halkın katılımı ve süreçte temsilin nasıl gerçekleştirildiği, kurumsal kaynaklara erişimin sağlanması ve kurumlara güvenin arttırılması gibi hususlar demokrasi teşviki gündeminin önemli faktörleridir (Silander \& Nilsson, 2014, s. 463). Ermenistan'ın ulusal sisteminin bu faktörler bağlamında gösterdiği gelişme değerlendirildiğinde, demokrasinin yerleşik olmasından ziyade düşük yoğunluklu bir demokrasinin (low intensity democracy) ağır bastığı gözlemlenmektedir (Freire \& Simao, 2013, s. 180). Bu durum Ermenistan'daki iç siyasetin karakteristiği ile ilişkili olarak düşük sivil katılım, çok partili siyasi ve sivil gruplaşmaların yetersiz kalması, hukukun üstünlüğü ilkelerinin ihlali gibi sorunların varlığından kaynaklanmaktadır. Ayrıca, Ermenistan'ın eski devlet başkanları Robert Koçaryan ve Serj Sarkisyan dönemleri analiz edildiğinde, Ermenistan geleneksel iç siyasetinin bir belirleyicisi olan ve demokratikleşme sürecinde etki oluşturan Dağlık Karabağ meselesinin elitler tarafından merkeze konumlandırılması oldukça önemlidir (Sasse, 2013, s. 574). Bu durum, Ermenistan'ın siyasi ve ekonomik işleyişine yön vermekte ve "geleneksel" olarak adlandırılan bir yönetim anlayışı ortaya çıkmaktadır (Freire \& Simao, 2013, s. 180). Ermenistan ve Azerbaycan arasındaki Dağlık Karabağ meselesinde çözümün sağlanamaması, yalnızca bölgesel işbirliğinde karmaşı 
Fulya Akgül Durakçay, Özge Bozkaya, “Avrupa Komşuluk Politikası’nda Demokrasi Teșviki: Ermenistan Örneği ve İç Dinamiklerin Değerlendirilmesi”, İstanbul Gelişim Üniversitesi Sosyal Bilimler Dergisi, 6 (2), Ekim 2019, ss. 223-247.

bir yapıya işaret etmemekte; aynı zamanda bu iki ülkedeki demokrasi teşviki sürecini de sekteye uğratmaktadır (Babayan, 2016, s. 221).

Ermenistan'daki yeni ve köklü bir açlıma işaret eden ve geleneksel yönetim anlayışına eklemlenen 6 Aralık 2015 tarihinde kabul edilen anayasa değişiklikleri ile yarı başkanlık sisteminin yerine birçok yetkinin başbakanın elinde toplandığı parlamenter sisteme geçilmiştir (Tartes, 2015, s. 18-19; Freedom House, 2017). Parlamenter sisteme geçiş, söz konusu anayasa değişikliği ve reform süreci, dönemin Devlet Başkanı Serj Sarkisyan'ın siyasi kontolünü devam ettirmek için izlediği bir hamle olarak yorumlanmıştır. Bu çerçevede iktidara yönelik kaygılar ve "otoriter rejim" tartışmaları artış göstermiștir (Abebe vd., 2017, s. 65-66).

1995 Anayasası ile kurulan yarı-başkanlık sisteminde ise, parlamentoyu dağıtma yetkisinin cumhurbaşkanının elinde toplandığı bir yapı söz konusuydu. 2005 yılında gerçekleștirilen anayasa reformu ile cumhurbaşkanının yetki genişliği parlamentonun rolünün güçlendirilmesi yoluyla azaltılmaya çalıșılsa da, cumhurbaşkanının siyasi kontrolünü yeterince sınırlandırmamıștır (Markarov, 2016, s. 88-89; Abebe vd., 2017, s. 65-66). 2015 yılında gerçekleștirilen anayasal paket ile benimsenen parlamenter sistemde ise, parlamento ve başbakanın yetkilerinin artırıldığı ve cumhurbaşkanının parlamentodaki milletvekilleri tarafından seçileceği bir mekânizma benimsenmiștir. Söz konusu mekânizma ise, yürütme, yasama ve yargı organlarının parlamenter çoğunluğun etkisi altında işlemesi, tek partili çoğunluğun siyasi kontrolde etkinliğinin artması, Anayasa Mahkemesi hâkimlerinin atanmasında parlamentodaki çoğunluk partisinin söz hakkının fazla olması gibi hususları gündeme getirmektedir. $\mathrm{Bu}$ durum da, demokratikleșme sürecinde birtakım endișeler yaratmaktadır (Abebe vd., s. 67-68).

Ermenistan'daki demokrasi teşvikinin temel belirleyicilerinden olan geleneksel yönetim anlayışının ise, "Kadife Devrim" olarak adlandırılan halk gösterilerinin ardından göreve gelen ve Ermenistan halkının iradesini temsil ettiği söylenen yeni Devlet Başkanı Nikol Paşinyan döneminde nasıl șekillendirileceği hala gündemde olan bir tartışma konusudur (Markarov, 2018, s. 3). Bu anlamda, patronal başkanlık sisteminin (patronal presidentialist) uzun yıllar Ermenistan geleneksel yönetim sisteminin temelinde yer almasının ardından, Sovyet sistemininin bıraktığı yönetim mirasından, Avrupalılaşmanın sağlandığı ve tam bir demokratikleşmenin gerçekleştirildiği bir sisteme geçiş Ermenistan'ın hâlihazırda sahip olduğu yapı düşünüldüğünde optimistik bir anlayışı temsil etmektedir (Özdaşlı, 2016, s. 143-144).

Bir ülkedeki demokrasi temsilinin yapı taşı olan şeffaf seçimlerin gerçekleştirilmesi hususu Ermenistan için uzun yllar üzerinde tartışılan bir sorun olmuştur (Freedom House, 2017). Özellikle, 19 Şubat 2008 tarihli başkanlık seçimleri neticesinde \%52.82'lik oy oranı alan Serj Sarkisyan'ın eski Başkan Ter-Petrosyan'ı geride bırakması ile, başkent Erivan'ın Cumhuriyet Meydanı'nda seçimlerin şeffaf olmamasının protesto edilmesi ve bu gösterilerin 1 Mart 2008 tarihinde kolluk kuvvetlerinin müdahalesi ile şiddet olaylarına dönüşmesi ileride gösterilerin yasaklanması ve medyanın sansürlenmesi ile devam etmiștir (Smith, 2012, s. 27). AB ve AGİT standartları ile uyuşmayan ve insan hakları ihlallerinin yaşandığı bu olaylar, Ermenistan'da karar alma ve seçim süreçlerinde rolü kuvvetli olan siyasi elitlerin demokratik reformlara uyum konusunda isteksizliği ile ilişkilendirilmektedir (Babayan, 2016, s. 220).

2013'te Ermenistan ile AB arasında Ortaklık Anlaşması'nın bir ayağı olan Derin ve Kapsamlı Serbest Ticaret Anlașması'nın müzakereleri tamamlanmıș olsa da yürürlüğe girememiș ve uygulama süreci başlatılamamıștır. Bunun en büyük nedeni ise Ermenistan'ın Kasım 2013'te düzenlenen Avrupa Doğu Komşuluğu Zirvesi'nden iki ay önce Rusya'nın girişimi olan Avrasya Gümrük Birliği'ne katılım hususunda müzakere kararı almasıdır (Babayan, 2016, s. 221). Nihayetinde de Ermenistan Ekim 2014'te AB entegrasyon sürecine benzerliği ile gündeme gelen, aşamalı bir entegrasyon sürecinin 
Fulya Akgül Durakçay, Özge Bozkaya, “Avrupa Komşuluk Politikası’nda Demokrasi Teșviki: Ermenistan Örneği ve İç Dinamiklerin Değerlendirilmesi”, İstanbul Gelişim Üniversitesi Sosyal Bilimler Dergisi, 6 (2), Ekim 2019, ss. 223-247.

benimsendiği Avrasya Birliği'ne katılım anlaşmasını imzalamış ve anlaşma 2 Ocak 2015’te yürürlüğe girmiştir.

Avrasya Ekonomik Birliği ile üye devletler arasında malların, hizmetlerin, sermayenin ve işgücünün serbest dolaşımının öngörüldügü bir ekonomik entegrasyon oluşturulması fikri ise (Eurasian Economic Union Official Website), Ermenistan'daki muhalefet tarafından bazı eleștiriler almıştır. Örneğin, Ermenistan eski Başbakanı Tigran Sarkisyan, Rusya ile Ermenistan'ın herhangi bir coğrafi sınırının bulunmamasının, ekonomik entegrasyonu sınırlandırdığı üzerinde durmuştur (Özdașlı, 2016, s. 143). Ayrıca ülke içindeki muhaliflerin üzerinde durduğu bir diğer önemli konu ise, ulusal egemenliğin uluslarüstü kurumlara veya birliğe devredilmesinin Ermenistan Anayasası'na aykırı olduğudur. Söz konusu eleștirilere rağmen Ermenistan, bugün Avrasya Ekonomik Birliği olan entegrasyon șeklinin üyelerinden biridir. Dolayısıyla, AB'nin Ermenistan ile ekonomik ilișkilerinin koșulluluk ilkesine bağlı tutulduğu demokrasi teşviki girişimleri, Rusya'nın Ermenistan ile kurduğu tarihsel yakınlık, bölgedeki kırılganlıklar üzerinden geliștirdiği ve Sovyet döneminden miras kalan ilișkiler ağından ayrı düşünülememektedir (Tartes, 2015, s. 18).

Donmuş çatıșma alanı Dağlık Karabağ meselesi, Ermenistan'ın enerji konusundaki bağımlılığı, coğrafik olarak Güney Kafkasya'daki "izole ülke" özelliği hususları Ermenistan'ın stratejik ortak olarak Rusya'ya ihtiyacını artırmaktadır. "Eşitsiz ittifak" (unequal alliance) olarak tanımlanan ve Rusya'nın Güney Kafkasya'daki nüfuz derecesini kuvvetlendiren ortaklıkta, Ermenistan'ın iç dinamiklerine doğrudan etki eden "güvenlik" en önemli faktörlerden biridir (Chitaladze \& Grigoryan, 2015, s. 35; Loda, 2017, s. 279). Bunun en temel örneği ise, Ermenistan'da konuşlanan Rus askeri üsleridir. Zira, Ermenistan'ın 2010 yılında aldığı bir kararla 2044 yılına kadar Gümrü'deki askeri üssünü Rusya'ya kiralamaya devam edecek olması, güvenlik ayağındaki bu ortaklığın uzun vadeli olduğunu göstermektedir (Loda, 2017, s. 279).

$\mathrm{Bu}$ ortaklıkta dikkat çeken bir diğer girișim ise 23 Aralık 2015 tarihinde Moskova'da imzalanarak, Haziran 2016'da Ermenistan Parlamentosu tarafindan kabul edilen "Birleşik Ordu Grubu Anlaşması"dır. Grubun temel görevleri, iki ülkenin karşılaşabileceği saldırı durumlarında, ortak bir savunma mekânizmasının işletilmesi, iki ülkenin kara, hava ve uzay sınırlarının korunmasında ortak hareket edilmesi yer almaktadır. Bu anlaşma, Rusya'nın Ermenistan'daki askeri varlığını daha ileri bir aşamaya taşıyan, askeri ve ekonomik işbirliğinin ötesine geçen bölgesel politikaların geliştirilmesi açısından da oldukça önemlidir (Asker, 2017, s. 78-79). Ayrıca, Ermenistan enerji ile ilişkili varlıklarını 2000-2001 döneminde uzun süredir sahip olduğu uluslararası borcu karşılığında Rusya'ya satmış ve sonrasında İran'a uzanan boru hatlarının büyük bir kısmı Rusya'ya devredilmiştir. Bunun ardından, 2014 yılında Ermenistan'ın enerji sektöründe Rusya'ya tamamen bağımlılığına yol açacak bir anlaşmaya varılmış, Gazprom tüm Ermeni gaz sektörünü satın almış ve Ermenistan'ın 2043 yılına kadar alternatif tedarikçilerden gaz almayacağının taahhütünü almıştır (Loda, 2017, s. 280).

Ermenistan'ın güvenlik ve ekonomi konularında bağımlılığının yanında kültürel ve toplumsal anlamda Rusya ile süregelen bir yakınlığının olması da önemli bir faktördür. Kafkasya Barometer 2015 verilerine göre, Ermenilerin \%75'i Rusya'yı Ermenistan'ın en yakın dostu olarak tanımlamaktadır (Caucasus Research Center, 2015). Fakat bu durum, Ermenistan halkının Rusya'nın tüm politikalarını desteklediği anlamını da taşımamaktadır. Rusya'nın bazı politikalarına karşı Ermenilerin artan memnuniyetsizliği ise, Ermenistan halkının daha çok $A B$ destekleyicisi bir tutumda olacağına da işaret etmemektedir. (Loda, 2017, s. 281). Ancak, Ermenistan'daki siyasi elitlerin davranışlarının ve iç dinamiklerin şekillenmesinde önemli bir etki alanına sahip olan Avrupa'daki diaspora Ermenileri, Ermenistan'ın diş ilişkilerinde AB gibi diğer aktörlere olan yönelimine neden olabilmektedir (Vieira \& Vasilyan, 2018, s. 477). Bu durum ise, 
Ermenistan'ın Rusya ve AB ile ilişkilerinde denge mekânizmasına yönelmesine neden olan unsurlardan biridir (Özdaşl, 2016, s. 143).

Rusya'nın Ermenistan ile işbirliğinin derin bir şekilde hissedildiği ve AB'ye üyeliğin söz konusu olmadığı bir ortamda, Ermenistan'ın iç dinamiklerinin şekillendirilmesinde hayati önem taşıyan demokrasinin teşvik edilmesi, yerel liberal elitlerle derin bir işbirliği kurulması ve sivil toplumun teşvik edilmesi AB için güç bir hal almaktadır (Babayan, 2016, s. 221). Dolayısıyla Ermenistan'ın iç dinamiklerinin şekillenmesinde etkili olan Rusya ve $\mathrm{AB}$ arasında kendine özgü bir denge mekânizması oluşturması, ayrıca demokrasi teşvikinin oldukça kırılgan bir yapıya sahip olması, Ermenistan'ın hem koşulluluk, hem de sosyalleşme mekânizmasına entegrasyonu anlamında karmaşık bir yapı meydana getirmektedir.

$\mathrm{AB}$ demokrasi teşvikinin diğer önemli bileșeni komşuluk ülkelerindeki sivil toplum faaliyetlerinin güçlendirilmesidir. $\mathrm{Bu}$ doğrultuda ülkelerdeki sivil toplum örgütlerinin kurulması yönünde fonlar ayrılmakta ve örgütlerin faaliyetleri desteklenmektedir. $\mathrm{AB}$ diğer komşularında olduğu gibi Ermenistan'da da sivil toplum örgütlerinin geliştirilmesine önem verse de, bu kapsamda izlediği politikalar Sovyet döneminde sivil toplum faaliyetlerinin çoğunun devlet eliyle gerçekleştirilmesinden kaynaklanan gelenek sebebi ile yeterince etkili olamamaktadır (Paturyan \& Gevorgyan, 2014, s. 15). Sovyet sonrası dönemde, Ermenistan'da sivil toplumun sınırlı bir gelişim gösterdiği söylenebilir.

Sovyet sonrası dönemde şekillenen ulusal bir sistem yaratma sürecinde ise sivil toplum örgütlerinin gelişimi aşamalı ve uzun vadeli bir programa ihtiyaç duyduğundan bu konuda Ermenistan'da yalnızca kısmi ve sınırlı bir gelişim kaydedilmiștir (Loda, 2017, s. 283). Ermenistan'da diğer eski Sovyet ülkelerinin çoğuna paralel bir şekilde kurumlar ve halk arasında negatif bir ilişkiden söz edilmektedir. Sivil toplum örgütleri, hükümet dışı, kar gütmeyen ve yerel halkın değer ve çıkarlarını temsil eden yapılar olsa da, Ermenistan'da kurumlara duyulan güvensizlik, bu örgütlerin işleyişine ve çlktılarına etki etmektedir (Loda, 2017, s. 283). Sivil toplum örgütlerinin gelişiminin kurumlara güvensizlik ile olan yakın ilișkisi, devlet ve sosyal ağların/örgütlenmelerin birbirini besleyen özelliğinden kaynaklanmaktadır. Ermenistan'da ise toplumun devlet eliyle yapılan özelleştirmeler, yolsuzluk, ekonomik sorunlar ve informal ağların birçok alanda etki alanına sahip olması nedeni ile kurumlara karşı güvensizlik hissetmesi, hükümet dışı örgütlere de şüpheci yaklaşmasına neden olmaktadır. Hatta Ermeni halk tarafından birçok sivil toplum örgütü "hibe yiyici" (grant eaters) olarak değerlendirilmektedir. 2015 Caucasus Barometer verilerine göre, Ermenilerin yalnızca yüzde 3'ü sivil toplumlarına tamamen güvendiğini, yüzde 19 'u ise biraz güvendiğini dile getirmiştir (Caucasus Research Center, 2015; Loda, 2017, s. 283-284).

Ermenistan'ın iç siyasetindeki geleneksel yönetim anlayışı, bu anlayışın kurumlara etkisi, elitlerin politika tercihleri, Rusya'nın Ermenistan'ın iç dinamikleri konusundaki belirleyiciliği, sivil toplum örgütlerinin yeterince gelişmemiş olması gibi hususların etkisi düşünüldüğünde, $A B$ 'nin demokrasi teşvikinin etkinliğinin sınırlı kaldığı açıktır. Bu yüzden, Avrupa Komşuluk Politikası ve Doğu Komşuluğu Girişimi çerçevesinde AB'nin Ermenistan'da demokrasi teşviki, iç dinamiklerin belirleyici etkisinin olduğu karmaşık bir tabloya işaret etmekte ve Avrupalılaşma için sınırları olan bir etkinlik alanı sunmaktadır.

\section{Sonuç}

AB'nin genişleme politikasında aday ülkelerin demokratikleşmesine yaptığg katkı ile demokrasi teşvikinde yakaladığı başarı geniş kabul görmektedir. Ancak, AB'nin bu başarısı üyelik sürecinde ödülün büyüklüğüne ve koşulluluk mekânizmasının etkililiğine 
bağlanmaktadır. AB norm, değer ve kurallar bütünün Komşuluk Politikası'na dâhil olan ülkelere transferi ve Avrupalılaşmanın bu ülkelere nüfuz etme derecesi literatürdeki temel tartışma konularından biridir. AB'nin sınırlı etkiye sahip olduğu Ermenistan'da Komşuluk Politikası aracılığı ile uygulanan demokrasi teşvikine rağmen düşük yoğunluklu demokrasinin varlığını sürdürmesi söz konusu tartışma açısından somut bir örnek sunmaktadır. Üyelik vaadinin yokluğunda koşulluluk mekânizmasının sınırlılığı ve Avrupa norm, değer ve kurallarının sosyalleşme aracılığı ile komşu ülkeler tarafından içselleștirilmesinin genişleme politikasına klyasla zorluğu, AB'nin talep ettiği siyasi reformları gerçekleștirmede komşu ülkelerin irade, isteklilik ve yetkinliklerini başat bir etken kılmaktadır.

Ermenistan'da demokratik unsurların güçlendirilmesinde seçimlerde şeffaflık, demokratik kurumsallaşmanın sağlanması, sivil toplumun güçlendirilmesi, yönetim anlayıșının demokratikleştirilmesi gibi hususların önemi göz önünde bulundurulduğunda, sosyalleşme ve Avrupalılaşma süreçleri bağlamında düşük katılımın gerçekleștiği söylenebilir. Böylelikle, AB'nin demokrasi teşvikinin Ermenistan'daki etkinlik derecesinin sorgulanması, Ermenistan'ın kendi iç dinamiklerinden ayrı düşünülememektedir. Ermenistan'daki geleneksel yönetim anlayışının otoriter rejim tartışmaları altında konumlanması, düşük sivil toplum katılımının gözlemlenmesi, şeffaf ve demokratik seçimlerin gerçekleştirilmesinde yakın tarihe kadar ciddi sorunların yaşanması, sivil toplum örgütlerinin konumunun zayıf kalması gibi hususlar demokrasi teşvikinin etkisinin tartışmalı olduğu bir ülke örneği sunmaktadır. $A B$, sosyalleșme mekânizmasının kullanılmasına verdiği önemi artırmış ve sosyalleşme süreçlerinde etkileșimde bulunduğu aktörleri çeşitlendirmiştir. Özellikle Doğu Ortaklığı Girişimi'nde sivil toplum sosyalleşme sürecinin en önemli aktörlerinden biri olarak tanımlanmıştır. Ancak; Ermenistan'da sivil toplumun gelişimini belirleyen iç dinamikler AB etkisini sınırlandırmaktadır. Örneğin; ülkede halkın sivil toplum örgütlerine yönelik olumsuz algıları ve güvensizliği, sivil toplumun demokratikleşme sürecinde destekleyici bir aktör haline gelmesi için AB'nin teknik ve finansal desteğinin tek başına yeterli olmadığını göstermektedir.

AB'nin komşu ülkelerde demokrasi teşviki sağlamak istemesinin başlıca nedenlerinden biri güvenlik anlayıșı ile ilișkilendirilmektedir. Daha güvenli bir Avrupa coğrafyasına sahip olmanın, komşulardaki güvenliğin, barış ortamı ve demokrasinin varlığı ile sıkı sıkıya bağlı olduğu bir anlayıșta, iç dinamikler bağlamında karmaşık bir yapıya sahip olan Ermenistan ve Güney Kafkasya coğrafyasında normatif baskı Birliğin izlediği yapısal dış politikanın ötesinde bir yaklaşıma ihtiyaç duymaktadır. Ekonomik ve finansal anlamda Avrupa pazarına entegrasyon ve ticari ilişkilerin belirli bir seviyede tutulmasının ötesinde, AB'nin normatif olarak Ermenistan'da etkili bir aktör haline gelebilmesi ülkede ve bölgede rolü kuvvetli olan Rusya'nın etki derecesine alternatif politikalar üretilmesi, demokratik unsurların șekillenmesinde hayati öneme sahip DağlıkKarabağ meselesi için proaktif çatışma çözümü yaklaşımının geliştirilmesi ve AB'nin koşulluluk mekânizmasını seçiciliğin ötesinde uygulaması ile yakından ilișkilidir. Ayrıca Ermenistan'ın seçilmiş Başkanı olarak ifade edilen Paşinyan yönetiminde, demokratik unsurlarının kuvvetlendirilmesi konusunda yeni işbirliklerinin geliştirilmesi de oldukça önemlidir. Demokrasi teşviki bağlamında zayıf bir ilerlemenin görüldüğü Ermenistan'da, Birliğin Komşuluk Politikası ve yaklaşımının en önemli tamamlayıcısı iç dinamiklerdir. 
Fulya Akgül Durakçay, Özge Bozkaya, “Avrupa Komşuluk Politikası’nda Demokrasi Teșviki: Ermenistan Örneği ve İç Dinamiklerin Değerlendirilmesi”, İstanbul Gelişim Üniversitesi Sosyal Bilimler Dergisi, 6 (2), Ekim 2019, ss. 223-247.

\section{KAYNAKÇA}

ABEBE, A. K., BISARYA, S., BÖCKENFÖRDE, M., BULMER, W. E., DALY, T. G., HUBBARD, E., MEYER-RESENDE, M., NGENGE, Y. (2017). Annual review of constitutionbuilding process: 2016. International Institute for Democracy and Electoral Assistance, Sweden.

Armenpress. (17.01.2012). EU and OSCE to support democratic election in Armenia. Erișim tarihi: 19.11.2018, https://armenpress.am/eng/news/675691/

ASKER, A. (2010). Ermenistan'da anayasal dönüşüm süreci ve Anayasa'nın temel özellikleri. Ermeni Araștırmaları Dergisi, (36), 191-218.

ASKER, A. (2017). The advanced stage of Russia-Armenia military cooperation: the joint military force. Review of Armenian Studies, (35), 59-91.

AVERY, G. (2015). EU Expansion and Wider Europe. The European Union: how does it work (ss. 163-186). Oxford: Oxford University Press.

BABAYAN, N. (2016). A global trend EU-style: Democracy promotion in 'fragile' and conflict-affected South Caucasus. Global Policy, Cilt 7 (2), 217-226. doi: 10.1111/1758-5899.12305

BALKIR, C. \& SOYALTIN, D. (2018). Avrupalılaşma: tarih, kavram, kuram ve Türkiye uygulaması, İstanbul: İstanbul Bilgi Üniversitesi Yayınları.

BARACANI, E. (2010). US and EU Strategies for Promoting Democracy. The foreign policy of the European Union: assessing Europe's role in the world (ss. 306-324). Washington: Brookings Institution Press.

BÖRZEL, T.A. \& LEBANIDZE, B. (2017). 'The transformative power of Europe' beyond enlargement: the EU's performance in promoting democracy in its neighbourhood. East European Politics, Cilt 33 (1), 17-35. doi:

10.1080/21599165.2017.1280473

BRAITHWAITE, M., EBERHARDT E. \& JOHNSON, T. (1998). The European Union's Phare and Tacis Democracy Programme - compendium of ad-hoc projects 1993-1997, Brown \& Milavec Publication Services.

Caucasus Research Center. (2015). Datasets: Main Friend of the Country. Erişim

Tarihi: 13.11.2018, http://caucasusbarometer.org/en/cb2015am/MAINFRN/

Caucasus Research Center. (2015). Datasets: Trust-NGOs. Erișim Tarihi:

13.11.2018, http://caucasusbarometer.org/en/cb2015am/TRUNGOS/

CAROTHERS, T. (2009, Ocak). Democracy assistance: political vs. developmental?. Journal of Democracy, Cilt 20 (1), 5-19.

CHECKEL, J.T. (2005). International institutions and socialization in Europe: introduction and framework. International Organization, Cilt 59 (4), 801-826. doi: $10.1017 /$ S0020818305050289

CHITALADZE, A. \& GRIGORYAN, T. Understanding Europeanization in Georgia and Armenia -discourses, perceptions and the impact on bilateral relations, Analytical Bulletin (8), 29-54.

Commission of the European Communities. (23.05.1995). Communication from the Commission on the inclusion of respect for democratic principles and human rights in agreements between the Community and third countries. Erişim tarihi: 26.09.2018, http://aei.pitt.edu/4097/1/4097.pdf

Commission of the European Communities. (11.03.2003). Wider Europe neighbourhood: a new framework for relations with our Eastern and Southern neighbours. Erişim tarihi: 12.09.2018, http://eeas.europa.eu/archives/docs/enp/pdf/pdf/com03 104 en.pdf

Commission of the European Communities. (12.05.2004). European Neighbourhood Policy Strategy Paper. Erişim tarihi: 13.09.2018, 
Fulya Akgül Durakçay, Özge Bozkaya, "Avrupa Komşuluk Politikası’nda Demokrasi Teşviki: Ermenistan Örneği ve İç Dinamiklerin Değerlendirilmesi”, İstanbul Gelişim Üniversitesi Sosyal Bilimler Dergisi, 6 (2), Ekim 2019, ss. 223-247.

https://ec.europa.eu/neighbourhood-enlargement/sites/near/files/2004 communication from the commission__european_neighbourhood policy_strategy paper.pdf

Commission of the European Communities. (03.12.2008). Communication from the Commission to the European Parliament and the Council - Eastern Partnership. Erişim tarihi: 10.10.2018, https://eur-lex.europa.eu/legalcontent/EN/TXT/PDF/?uri=CELEX:52008DC0823\&from=EN

Council of the European Union. (15.04.2002). 2421st Council meeting - general affairs. Erişim tarihi: 13.10.2018, http://www.consilium.europa.eu/uedocs/cms data/docs/pressdata/en/gena/70160.pdf

Council of the European Union. (05.03.2008). Declaration by the Presidency on behalf of the EU on the situation after the presidential election in Armenia on 1st March 2008, Erişim tarihi: 19.11.2018),

https://www.consilium.europa.eu/ueDocs/cms Data/docs/pressData/en/cfsp/99186.pdf

Council of the European Union. (07.05.2009). Joint Declaration of the Prague Eastern Partnership Summit. Erişim tarihi: 09.11.2018, https://www.consilium.europa.eu/media/31797/2009 eap declaration.pdf

Council of the European Union. (17.11.2009). Council conclusions on democracy support in the EU's external relations. Erişim tarihi: 03.10.2018.

https://www.consilium.europa.eu/uedocs/cms data/docs/pressdata/en/gena/111250.pdf

DANDASHLY, A. (2018). EU democracy promotion and the dominance of the security-stability nexus. Mediterranean Politics, Cilt 23 (1), 62-82. doi:

10.1080/13629395.2017.1358900

DEMIRAĞ, Y. (2004-2005). EU policy towards South Caucasus and Turkey. Perceptions, Winter, 91-105.

DUCHENE, F. (1973). The European Community and the Uncertainties of Interdependence. A nation writ large? Foreign policy problems before the European Community (ss. 1-21). Londra: Palgrave Macmillan.

EFEGIL, E. (2008). Avrupa Birliği'nin Orta Asya politikasının analizi: proje bazlı yaklaşımdan stratejik işbirliği anlayışına geçiş. Akdeniz IiBF Dergisi, Cilt 16, 65-82.

ERDENIR, B. (2012, Aralık) Türkiye'nin siyasi reform sürecinde Avrupa Birliği'nin demokratik koşulluluğu. TODAIE Amme İdaresi Dergisi, Cilt 45 (4), 95-117.

Eurasian Economic Union Official Website. About the Union. Erişim tarihi:

09.04.2019, http://www.eaeunion.org/?lang=en\#about

European Commission. (06.12.2002). A wider Europe- a proximity policy as the key to stability - Romano Prodi speech. Erişim tarihi: 12.09.2018,

http://europa.eu/rapid/press-release SPEECH-02-619 en.htm

European Commission. (08.03.2011a). Joint communication to the European Council, the European Parliament, the Council, the European Economic and Social Committee and the Committee of the Regions - a partnership for democracy and shared prosperity with the Southern Mediterranean. Erişim tarihi: 26.09.2018, https://ec.europa.eu/research/iscp/pdf/policy/com_2011_200_en.pdf

European Commission. (25.05.2011b). Joint communication by the High Representative of the Union for Foreign Affairs And Security Policy and the European Commission - A new response to a changing neighbourhood: a review of European Neighbourhood Policy. Erişim tarihi: 26.09.2018, https://library.euneighbours.eu/content/new-response-changing-neighbourhood-revieweuropean-neighbourhood-policy

European Commission. (20.02.2013). Joint Statement by EU High Representative Catherine Ashton and Commissioner Stefan Füle on elections in Armenia. Erişim tarihi: 19.11.2018, http://europa.eu/rapid/press-release_MEMO-13-125_en.htm 
Fulya Akgül Durakçay, Özge Bozkaya, "Avrupa Komşuluk Politikası’nda Demokrasi Teşviki: Ermenistan Örneği ve İç Dinamiklerin Değerlendirilmesi”, İstanbul Gelişim Üniversitesi Sosyal Bilimler Dergisi, 6 (2), Ekim 2019, ss. 223-247.

European Commission. (2014a). European Neighbourhood and Partnership Instrument 2007-2013 - overview of activities and results. Erişim tarihi: 19.09.2018, https://ec.europa.eu/europeaid/sites/devco/files/overview of enpi results 2007$\underline{2013 \text { en 0.pdf }}$

European Commission. (27.03.2014b). Implementation of the European Neighbourhood Policy in Armenia progress in 2013 and recommendations for action. Erişim tarihi: 07.11.2018, https://library.euneighbours.eu/content/armenia-enp-progressreport-2013

European Commission. (18.11.2015). Joint Communication to the European Parliament, the Council, the European Economic and Social Committee and the Committee of the Regions - review of the European Neighbourhood Policy. Erișim tarihi: 27.09.2018, http://eeas.europa.eu/archives/docs/enp/documents/2015/151118 jointcommunication review-of-the-enp en.pdf

European Commission. (25.09.2017). Joint proposal for a Council decision on the conclusion, on behalf of the European Union, of the Comprehensive and Enhanced Partnership Agreement between the European Union and the European Atomic Energy Community and their Member States, of the one part, and the Republic of Armenia, of the other part. Erișim tarihi: 12.11.2018, https://eur-lex.europa.eu/legalcontent/EN/TXT/?Uri=JOIN:2017:37:FIN

European Council in Copenhagen. (21-22.06.1993). Conclusions of the Presidency. Erişim tarihi: 10.09.2018, https://www.consilium.europa.eu/media/21225/72921.pdf

European External Action Service. (2006). EU/Armenia Action Plan, Erişim tarihi: 20.09.2018, https://eeas.europa.eu/sites/eeas/files/armenia enp ap final en.pdf

European External Action Service. (11.05.2016). Armenia and the EU. Erişim tarihi: 07.11.2018, https://eeas.europa.eu/delegations/armenia en/896/Armenia\%20and\%20the\%20EU

European External Action Service. (06.2016). Shared vision, common action: a stronger Europe - a global strategy for the European Union's Foreign and Security Policy. Erişim tarihi: 04.10.2018, http://eeas.europa.eu/archives/docs/top_stories/pdf/eugs_review_web.pdf

European External Action Service. (19.06.2018). Fact sheet on EU-Armenia relations. Erişim tarihi: 02.11.2018, https://eeas.europa.eu/topics/health/4080/factsheet-eu-armenia-relations_en

European External Action Service. Facts and figures about EU-Armenia Relations. Erişim tarihi: 03.04.2019, https://eeas.europa.eu/sites/eeas/files/eap summit factsheet armenia eng.pdf

European External Action Service Strategic Planning. (12.12.2003). European Security Strategy - a secure Europe in a better world. Erișim tarihi: 18.09.2018, https://europa.eu/globalstrategy/en/european-security-strategy-secure-europe-betterworld

European Parliament. (2017). The European Neighbourhood Policy. Erişim tarihi: 19.09.2018, http://www.europarl.europa.eu/RegData/etudes/fiches_techniques/2013/ 060504/04A FT(2013)060504 EN.pdf

European Union. (20.06.2011). Remarks by High Representative Catherine Ashton at the press conference after the Foreign Affairs Council. Erişim tarihi: 21.09.2018, http:// www.consilium.europa.eu/uedocs/cms Data/docs/pressdata/EN/foraff/122934.pdf

European Union. (08.05.2012). Statement by High Representative Catherine Ashton and Commissioner Stefan Füle on the Parliamentary elections in Armenia on 6 May 2012, Erişim tarihi: 19.11.2018), https://www.consilium.europa.eu/uedocs/cms data/docs /pressdata/EN/foraff/130097.pdf 
Fulya Akgül Durakçay, Özge Bozkaya, “Avrupa Komşuluk Politikası'nda Demokrasi Teșviki: Ermenistan Örneği ve İç Dinamiklerin Değerlendirilmesi”, İstanbul Gelişim Üniversitesi Sosyal Bilimler Dergisi, 6 (2), Ekim 2019, ss. 223-247.

European Union. (2017). The European Neighbourhood Instrument (ENI). Erişim tarihi: 20.09.2018, https://www.euneighbours.eu/en/policy/european-neighbourhoodinstrument-eni

EYLEMER, S. (2010). Avrupalılaşma sürecinde siyasi koşulluluk ve elitler: Türkiye örneği (Yayımlanmamış Doktora Tezi). Dokuz Eylül Üniversitesi Sosyal Bilimler Enstitüsü Avrupa Birliği Anabilim Dalı, İzmir.

Freedom House. (2018). Freedom in the World 2017: Armenia Profile. Erişim Tarihi: 15.11.2018, https://freedomhouse.org/report/freedom-world/2017/armenia

FREIRE, M.R. \& SIMAO, L. 'From words to deeds': European Union democracy promotion in Armenia. East European Politics, Cilt 29 (2), 175-189. doi: 10.1080/21599165.2013.780163

GÜLTEKIN-PUNSMANN, B. \& KRASSIMIR, Y. N. (2008). European Union approaches to fostering synergies of cooperation and integration around the Black Sea. South East European and Black Sea Studies, Cilt 8 (2), 109-128. doi: 10.1080/14683850802117500

GRABBE, H. (2006). The EU's transformative power: Europeanization through conditionality in Central and Eastern Europe, New York: Palgrave Macmillan.

HATİPOĞLU, E. (2004). Daha Geniş Avrupa: Avrupa Birliği (AB)'nin komşu ülkeler politikasının analizi. Avrupa Araștırmaları Dergisi, Cilt 12 (1-2), 221-233.

HUFF, A. (05.2011). The role of EU defence policy in the Eastern neighbourhood. Erişim tarihi: 10.10.2018, https://www.iss.europa.eu/sites/default/files/EUISSFiles/op91The role of EU defence policy in the Eastern neighbourhood 0.pdf

HÜRSOY, S. \& KUTLU, E. (2018). Yenilenen Avrupa Komşuluk Politikası perspektifinden Avrupa Birliği'nin Doğu komşularına yönelik yaklaşımı. Ege Stratejik Araștırmalar Dergisi, Cilt 9 (2), 169-189.

KAHRAMAN, S. (2005, Kış). The European Neighbourhood Policy: the European Union's new engagement towards wider Europe. Perceptions, 1-28.

KELLEY, J. (2006). New wine in old wineskins: promoting political reforms through the new European Neighbourhood Policy. Journal of Common Market Studies, Cilt 44 (1), 29-55. doi: 10.1111/j.1468-5965.2006.00613.x

KOENIG, N. (22.03.2016). Taking the ENP beyond the conception-performance gap. Erişim tarihi: 20.09.2018, https://institutdelors.eu/wpcontent/uploads/2018/01/enpstrategicorientation-koenig-jdib-mar16.pdf

KOSTANYAN, H. (2015). Neither Integrated Nor Comprehensive in Substance: Armenia and Georgia. The substance of EU democracy promotion: concepts and cases (ss. 134-148). Londra: Palgrave Macmillan.

KOSTANYAN, H. \& VANDECASTEELE, B. (05.2013). The EuroNest Parliamentary Assembly: The European Parliament as a socializer of its counterparts in the EU's Eastern Neighbourhood?. Erişim tarihi: 09.11.2018, https://www.ceps.eu/publications/euronestparliamentary-assembly-european-parliament-socializer-its-counterpartseu\%E2\%80\%99s

KUBICEK, P. J. (2003). International Norms, the European Union, and Democratization: Tentative Theory and Evidence. The European Union and democratization (ss. 1-29). London ve New York: Routledge.

LAVENEX, S. \& SCHIMMELFENNIG, F. (2011). EU democracy promotion in the neighbourhood: from leverage to governance? Democratization, Cilt 18 (4), 885-909. doi: $10.1080 / 13510347.2011 .584730$

LEONARD, M. (2005). Europe's transformative power. Erişim tarihi: 20.10.2018, https://www.cer.eu/publications/archive/bulletin-article/2005/europes-transformativepower 
Fulya Akgül Durakçay, Özge Bozkaya, “Avrupa Komşuluk Politikası'nda Demokrasi Teșviki: Ermenistan Örneği ve İç Dinamiklerin Değerlendirilmesi”, İstanbul Gelişim Üniversitesi Sosyal Bilimler Dergisi, 6 (2), Ekim 2019, ss. 223-247.

LEVITSKY, S. \& WAY, L. (2005). International linkage and democratization. Journal of Democracy, Cilt 16 (3), 20-34. doi: 10.1353/jod.2005.0048

MANNERS, I. (2002). Normative power Europe: a contradiction in terms?. Journal of Common Market Studies, Cilt 40 (2), 235-258. doi: 10.1111/1468-5965.00353

MARKAROV, A. (2016). Semi-Presidentalism in Armenia. Semi-Presidentalism in the Caucasus and Central Asia, United Kingdom: Palgrave Macmillan.

MARKAROV, A. (2018). Armenia's foreign policy priorities: Are there any major changes following the spring 2018 political transformation?. Caucasus Analytical Digest, (104), 3-7.

Official Journal of the European Communities. (29.07.1992). Treaty on European Union, Erişim tarihi: 17.09.2018, https://eur-lex.europa.eu/legalcontent/EN/TXT/PDF/?uri=CELEX:11992M/TXT\&from=EN

Official Journal of the European Communities. (09.09.1999). Partnership and Cooperation Agreement between the European Communities and their Member States, of the one part, and the Republic of Armenia, of the other part, Erișim tarihi: 02.11.2018, https://eeas.europa.eu/sites/eeas/files/euarmenia partnership and cooperation agreement en.pdf

Official Journal of the European Union. (26.10.2012). Consolidated Version of the Treaty on European Union, Erişim tarihi: 17.09.2018, https://eur-lex.europa.eu/resource. html?uri=cellar:2bf140bf-a3f8-4ab2-b506-fd71826e6da6.0023.02/DOC 1\&format=PDF

OLSEN, G.R. (2000). Promotion of democracy as a foreign policy instrument of 'Europe': limits to international idealism. Democratization, Cilt 7 (2), 142-167. doi: 10.1080/13510340008403663

ÖZDAŞLI, E. (2016). Avrupa Komşuluk Politikası çerçevesinde Avrupa BirliğiErmenistan ilişsileri. Aksaray Üniversitesi İktisadi ve İdari Bilimler Fakültesi Dergisi, Cilt 8 (1), 135-146.

ÖZKURT, F.Z. (2017). European Union democracy promotion via conditionality in regional context. İstanbul Gelişim Üniversitesi Sosyal Bilimler Dergisi, Cilt 4 (2), 1-21. doi: 10.17336/igusbd.324178

PATURYAN, Y. J. \& Gevorgyan, V. (2014). Armenian civil society after twenty years of transition: Still post-communist?, American University of Armenia, Turpanjian Center for Policy Analysis, Erişim Tarihi: 07.11.2018, http://tcpa.aua.am/files/2012/07/Armenian_Civil_Society_after_Twenty_Years_of_Tran sition Manuscript November 2014-fin.pdf

PRIDHAM, G. (1999). The European Union, Democratic Conditionality and Transnational Party Linkages - The case of Eastern Europe. Democracy without borders - transnationalization and conditionality in new democracies (ss. 59-75), Londra: Routledge.

RISSE, T. \& SIKKINK, K. (1999). The Socialization of International Human Rights Norms into Domestic Practices. The power of human rights: international norms and domestic change (ss. 1-38). Cambridge: Cambridge University Press.

SASSE, G. (2013). Linkages and the Promotion of Democracy: the EU's Eastern Neighbourhood, Democratization, Cilt 20 (4), 553-591.

SASSE, G. (2008). The European Neighbourhood Policy: conditionality revisited for the EU's Eastern neighbours. Europe-Asia Studies, Cilt 60 (2), 295-316. doi: $10.1080 / 09668130701820150$

SCHIMMELFENNIG, F. (2005, Güz). Strategic calculation and international socialization: membership incentives, party constellations, and sustained compliance in Central and Eastern Europe", International Organization, Cilt 59 (4), 827-860. doi: $10.1017 / \mathrm{S} 002081830505$ 
Fulya Akgül Durakçay, Özge Bozkaya, “Avrupa Komşuluk Politikası’nda Demokrasi Teșviki: Ermenistan Örneği ve İç Dinamiklerin Değerlendirilmesi”, İstanbul Gelişim Üniversitesi Sosyal Bilimler Dergisi, 6 (2), Ekim 2019, ss. 223-247.

SCHIMMELFENNIG, F., ENGERT, S. \& KNOBEL, H. (2003). Costs, commitment and compliance: the impact of EU democratic conditionality on Latvia, Slovakia and Turkey. Journal of Common Market Studies, Cilt 41 (3), 495-518.

SCHIMMELFENNIG, F. \& SEDELMEIER, U. (2002). Theorizing EU enlargement: research focus, hypotheses, and the state of research. Journal of European Public Policy, Cilt 9 (4), 500-528. doi: 10.1080/13501760210152411

SCHIMMELFENNIG, F. \& SEDELMEIER, U. (2004). Governance by conditionality: EU rule transfer to the candidate countries of Central and Eastern Europe. Journal of European Public Policy, Cilt 11 (4), 669-687. doi: 10.1080/1350176042000248089

SEDELMEIER, U. (2011). Europeanisation in new member and candidate states. Living Reviews in European Governance, Cilt 6 (1), 1-52.

SIMAO, L. (2012). The problematic role of EU democracy promotion in Armenia, Azerbaijan and Nagorno-Karabakh. Communist and Post-Communist Studies, Cilt 45 (1-2), 193-200, doi: 10.1016/j.postcomstud.2012.03.001

SILANDER, D. \& Nilsson, M. (2014). Protecting and Promoting Europe: The ENP and the Security-Democracy Nexus in Partner States, Journal of Applied Security Research, Cilt 9 (4), 460-477.

SMITH, K. (2005). The outsiders: the European Neighbourhood Policy. International Affairs, Cilt 81 (4), 757-773.

SMITH, N.R. (2011). Europeanization through socialization? the EU's interaction with civil society organizations in Armenia. Demokratizatsiya, 385-402.

SMITH, N.R. (2012). The EU's two-track promotion of democracy in its Eastern neighbourhood: examining the case of Armenia, Asia-Pacific Journal of EU Studies, Cilt 10, (1), 19-43. doi: 10.1080/13510347.2011.584734

SOLONENKO, I. (2009). External democracy promotion in Ukraine: the role of the European Union. Democratization, Cilt 16 (4), 709-791. doi: 10.1080/13510340903083851

ŞAHBAZOV, R. (2015). Yeni küresel sistemde Avrupa Birliği ve Güney Kafkasya: genişleme ve Komşuluk Politikası ekseninde. Ankara: EkoAvrasya Yayınları.

TARTES, A. (2015). The limited influence of the European Union in Armenia and Azerbaijan: A domestic explanation. College of Europe Department of EU International Relations and Diplomacy Studies, EU Diplomacy Paper, (9), 1-39.

TOLSTRUP, J. (2014). Russia vs. the EU: the competition for influence in post-Soviet states. Colorado ve Londra: Lynne Rienner Publishers.

ÜNAL ERIŞ, Ö. (2012). European Neighbourhood Policy as a tool for stabilizing Europe's neighbourhood. Southeast European and Black Sea Studies, Cilt 12 (2), 243-260. doi: 10.1080/14683857.2012.686012

VEEBEL, V. (2009). European Union's positive conditionality model in preaccession process. TRAMES, Cilt 13 (3), 207-231.

Vieria, A., \& Vasilyan, S. (2018). Armenia and Belarus: caught between the EU's and Russia's conditionalities?. European Politics and Society, Cilt 19 (4), 471-489. doi: 10.1080/23745118.2018.1455337

YAZGAN, H. (2012). Bir kavramsal çerçeve olarak 'Avrupalılaşma': kapsam, gereklilik ve sınırlar. Anadolu Üniversitesi Sosyal Bilimler Dergisi, 123-140.

YAZGAN, H. (2015). Genişleme Süreci, Avrupa ve Komşuları. Avrupa ve Avrupa Birliği: teori, güncel iç gelişmeler ve dış iliş̧kiler (ss. 245-269). Ankara: Savaş Yayınevi.

ZAMFIR, I. (03.2018). Democracy support in EU external policy. Erişim tarihi: 02.10.2018, http://www.europarl.europa.eu/RegData/etudes/BRIE/2018/614717/ EPRS BRI(2018)614717 EN.pdf 
Fulya Akgül Durakçay, Özge Bozkaya, “Avrupa Komşuluk Politikası'nda Demokrasi Teşviki: Ermenistan Örneği ve İç Dinamiklerin Değerlendirilmesi”, İstanbul Gelişim Üniversitesi Sosyal Bilimler Dergisi, 6 (2), Ekim 2019, ss. 223-247.

\section{Summary}

The European Union has evolved as an international democracy promoter actor since the 1990s as the security agenda of the international relations have changed with the end of the Cold War. The EU's success in promoting democracy has been mainly attributed to its enlargement strategy. As the EU's 2004 enlargement has changed its borders and neighbours towards the Eastern Europe, the EU has faced with new security challenges and the constraints on the sustainability of its enlargement strategy towards new neighbours. This in turn paved the way for a new approach towards its neighbours with offering less than membership but more than partnership. Accordingly, the European Neighbourhood Policy (ENP) merges with a foreign policy approach that expects the neighbourhood countries to realise political reforms for democratisation without a credible membership perspective and expects to create a ring of friends.

Democracy, human rights and the rule of law are fundamental values of the EU'S democracy promotion policies in the ENP. The EU combines democracy promotion with its security strategy as it takes democracy as the most stable and secure regime. The EU uses conditionality and socialization mechanisms in its democracy promotion strategies that are very dependent on the third country's desires, wills and competences to realize political reforms for democratisation. The transfer of the EU norms, rules and standards in the absence of a credible membership is a controversial topic in the EU studies literature. As this study indicates in the case of Armenia, the EU effect in post-Soviet countries is limited as the EU faces challenges arising from the political, economic and military influence of Russia and also the ongoing nation-state building processes in the post-Soviet sphere.

The EU expects from Armenia to realize political reforms focused on free, fair and transparent elections, strengthening the capacity of democratic institutions and empowerment of the civil society. The realisation of these expectations is interrelated to Armenia's internal dynamics. The lack of a democratic institutional structure, traditional administration approach with concentrating power on a few political elites, the problems encountered by civil society and the Russian influence in Armenia stay as determinant factors for the limited EU influence. The EU needs to address democracy promotion in Armenia beyond deepening economic and trade relations with consistent use of democratic conditionality, and produce alternative policies to Russian influence and proactive conflict resolution for the Nagorno-Karabakh issue. 